USE OF AN ULTRA-CLEAN SAMPLING TECHNIQUE WITH INDUCTIVELY COUPLED PLASMA-MASS SPECTROMETRY TO DETERMINE TRACE-ELEMENT CONCENTRATIONS IN WATER FROM THE KIRKWOOD-COHANSEY AQUIFER SYSTEM, COASTAL PLAIN, NEW JERSEY

By Tamara Ivahnenko, Zoltan Szabo, and Gene S. Hall

U.S. GEOLOGICAL SURVEY

Open-File Report 96-142

Prepared in cooperation with the NEW JERSEY DEPARTMENT OF ENVIRONMENTAL PROTECTION

W. Trenton, New Jersey 


\section{U.S. DEPARTMENT OF THE INTERIOR}

Bruce Babbitt, Secretary

\section{U.S. GEOLOGICAL SURVEY}

Gordon P. Eaton, Director

For additional information write to:

District Chief

U.S. Geological Survey, WRD

Mountain View Office Park

810 Bear Tavern Road

Suite 206

West Trenton, NJ 08628
Copies of this report can be purchased from:

U.S. Geological Survey

Earth Science Information Center Books and Open-File Reports Section Box 25286, Mail Stop 517

Denver Federal Center

Denver, CO 80225 


\section{CONTENTS}

Abstract.

Introduction

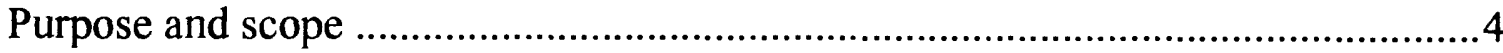

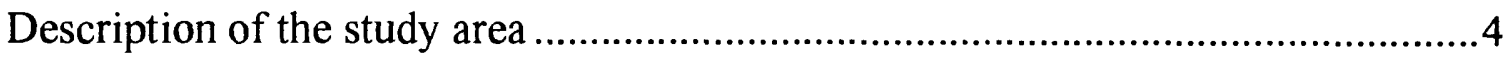

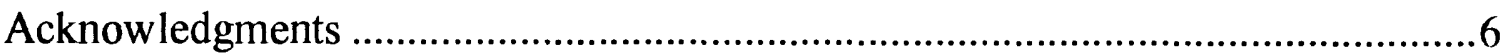

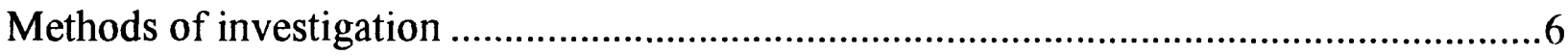

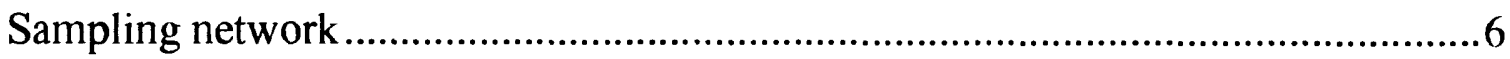

Ultra-clean trace-element sampling technique .................................................

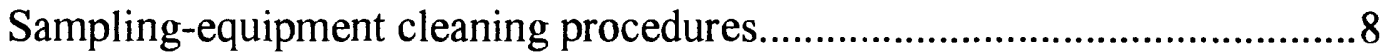

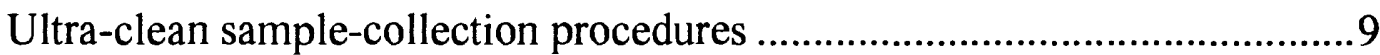

Procedures for collecting equipment blanks and split samples ...................11

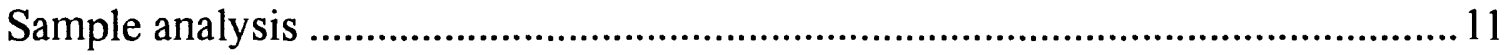

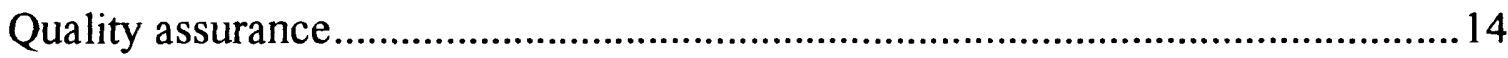

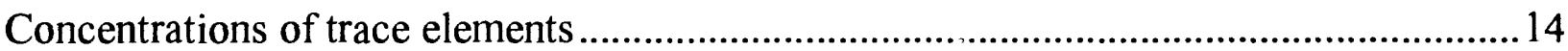

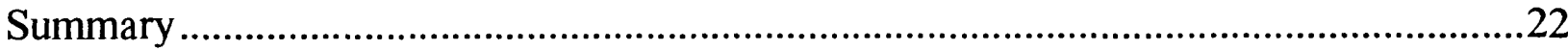

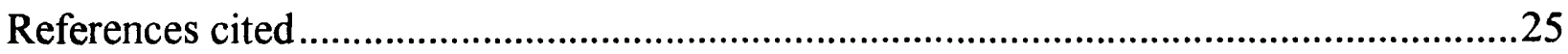

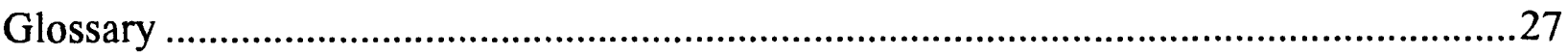

\section{ILLUSTRATIONS}

Figure 1. Map showing location of the outcrop of the Kirkwood Formation, the extent of the Kirkwood-Cohansey aquifer system, the extent of the Bridgeton Formation, agricultural land, and the public supply wells sampled, Coastal

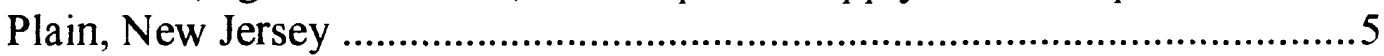

2. Graphs showing the concentrations of (a) zinc and (b) nickel in qualityassurance/quality-control split samples analyzed at the U.S. Geological Survey National Water Quality Laboratory and the Rutgers University Chemistry Department Laboratory, New Jersey, 1993

\section{TABLES}

Table 1. Well-construction data for selected public supply wells screened in the Kirkwood-Cohansey aquifer system, New Jersey, 1993

2. Analytical technique, minimum reporting limit, minimum limit of detection, and precision for trace elements in water samples from the KirkwoodCohansey aquifer system, New Jersey, 1993

3. Physical properties of, and concentrations of, trace elements, nutrients, calcium, magnesium, and selected radioactive elements and radionuclides in, water samples from public supply wells in the Kirkwood-Cohansey aquifer system, New Jersey, 1986-90 


\section{TABLES--Continued}

Table 4. Physical properties of, concentrations of trace elements in, and lead isotope ratios in water samples from selected public supply wells in the KirkwoodCohansey aquifer system, New Jersey, 1993

5. Statistical summary and distribution of selected trace elements, $\mathrm{pH}$, and turbidity in samples from selected public supply wells in the KirkwoodCohansey aquifer system, New Jersey, 1993

6. Results of analyses for concentrations of constituents in quality-assurance/ quality-control equipment blanks and reference standard for water samples collected during 1993, New Jersey

7. Relative percent difference in trace-element concentrations in split samples analyzed at the U.S. Geological Survey National Water Quality Laboratory and the Rutgers University Chemistry Department laboratory, and a quality-assurance/quality-control reference standard analyzed at the U.S. Geological Survey National Water Quality Laboratory, New Jersey, 1993 ... 19 


\section{CONVERSION FACTORS, VERTICAL DATUM, AND ABBREVIATED WATER-QUALITY UNITS}

Multiply

inch (in.)

foot $(\mathrm{ft})$

mile (mi)

square inch (in $\left.{ }^{2}\right)$

gallon (gal)

ounce, avoirdupois (oz)

pound, avoirdupois (lb)

degree Fahrenheit $\left({ }^{\circ} \mathrm{F}\right)$
By

Length

25.4

0.3048

1.609

Area

6.45

Volume

3.785

$\underline{\text { Mass }}$

28.35

0.4536
To obtain

millimeter

meter

kilometer

square centimeter

\section{Temperature}

$$
{ }^{\circ} \mathrm{C}=5 / 9 \times\left({ }^{\circ} \mathrm{F}-32\right)
$$

degree Celsius $\left({ }^{\circ} \mathrm{C}\right)$

Sea level: In this report "sea level" refers to the National Geodetic Vertical Datum of 1929--a geodetic datum derived from a general adjustment of the first-order level nets of the United States and Canada, formerly called Sea Level Datum of 1929.

Water-quality abbreviations:

L $\quad$ - Liter

$\mathrm{mg} / \mathrm{L}$ - milligrams per liter

$\mathrm{pCi} / \mathrm{L} \quad$ - picocuries per liter

$\mu \mathrm{S} / \mathrm{cm}$ - microsiemens per centimeter at 25 degrees Celsius $\mu \mathrm{g} / \mathrm{L}$ - micrograms per liter

$\mathrm{mg} / \mathrm{L}$ - milligrams per liter

DO - dissolved oxygen 


\title{
USE OF AN ULTRA-CLEAN SAMPLING TECHNIQUE WITH INDUCTIVELY COUPLED PLASMA-MASS SPECTROMETRY TO DETERMINE TRACE-ELEMENT CONCENTRATIONS IN WATER FROM THE KIRKWOOD-COHANSEY AQUIFER SYSTEM, COASTAL PLAIN, NEW JERSEY
}

\author{
By Tamara Ivahnenko, Zoltan Szabo, and Gene S. Hall
}

\begin{abstract}
Water samples were collected during 1993 from 22 public supply wells screened in the Kirkwood-Cohansey aquifer system; concentrations of 18 trace elements were determined primarily by using inductively coupled plasma-mass spectrometry (ICP-MS) techniques, though graphite furnace atomic adsorption, hydride generation, and coldvapor flameless atomic adsorption techniques were used for thallium, arsenic, and mercury, respectively, at the U.S. Geological Survey (USGS) National Water Quality Laboratory (NWQL). In addition, laboratory measurements of alkalinity and turbidity were made. The ground-water samples were collected by using ultra-clean sampling protocols developed by the USGS for collecting ground-water samples in areas with water containing low concentrations of trace elements. This technique is based on recently gained experience in sampling surface water for these elements. Field parameters (water temperature, specific conductance, $\mathrm{pH}$, and dissolved-oxygen concentration) were monitored prior to sample collection. Three equipment blanks were collected to ensure that low-level trace-element contamination did not occur during sample collection. One split sample and a commercially-prepared reference standard were submitted to the NWQL to evaluate laboratory precision and accuracy, respectively. Trace-element concentrations in 10 sample splits and one equipment blank were also determined at the Rutgers University Chemistry Department laboratory.

Results of the ICP-MS analyses and cold vapor flameless atomic absorption indicated that five trace elements-- cobalt, copper, lead, mercury, and nickel--were detectable in low concentrations $(<0.1-29 \mu \mathrm{g} / \mathrm{L})$ in most of the samples from the 22 wells, and four elements--aluminum, barium, manganese and zinc--were detected in higher concentrations than the other elements $(30-710 \mu \mathrm{g} / \mathrm{L}$ for aluminum; $4-180 \mu \mathrm{g} / \mathrm{L}$ for barium, manganese, and zinc). The remaining nine trace elements were present in concentrations consistently lower than the minimum reporting limit. Turbidity was low (less than 1 nephelometric turbidity unit (NTU)), indicating that the trace-element
\end{abstract}


concentrations were present in the dissolved phase and ideally would be reproducible in the absence of highly variable concentrations of particulates. The concentration of lead in one sample exceeded the U.S. Environmental Protection Agency (USEPA) action level of $15 \mu \mathrm{g} / \mathrm{L}$; concentrations ranged from $<1$ to $16 \mu \mathrm{g} / \mathrm{L}$. Mercury was frequently detected; concentrations ranged from $<0.1$ to $1.1 \mu \mathrm{g} / \mathrm{L}$ but did not exceed the USEPA maximum contaminant level.

Results of analyses of the equipment blanks indicated that samples collected by using the new ultra-clean sampling protocols were free of low-level $(<1 \mu \mathrm{g} / \mathrm{L})$ traceelement contamination. The analysis of the split sample sent to the NWQL had a difference of 5 percent or less for all constituents except aluminum, for which the analysis had a difference of 10 percent. Results of ICP-MS analyses of split water samples sent to the Rutgers University Chemistry Department laboratory were, in general, in good agreement (within 10 percent) with those of the NWQL. Results of the analysis of the commercial standard agreed (within 5 percent) with the known concentrations of the trace elements. The quality-assurance data (three blanks, one split sample, and one standard), although not statistically evaluated because of the small data set, indicate that the measured trace-element concentrations are precise and accurate and that the samples were free of contamination at the microgram-per-liter level of contamination.

\section{INTRODUCTION}

Accurate and precise analysis for trace elements in ground water at concentrations in micrograms per liter is necessary because large-scale dispersion of trace elements in the environment by human activity can lead to long-term degradation of ground-water quality. Human activities during the last 50 years have caused widespread changes in the distribution of trace elements in the environment. Large-scale increases in concentrations of lead (Chow and Earl, 1970) and mercury in the atmosphere (Swain and others, 1992) and lead in soils (Johnson and others, 1982) have been reported. The increase of these contaminants in air and soil could result in increased contamination of shallow, young ground water.

Chemical products widely dispersed through agricultural practices, road salting, and industrial practices have degraded the quality of ground water. Agricultural chemicals in recharge water filter through the aquifer system, resulting in the deterioration of the natural capacities of the aquifer matrix (sediment surfaces) to retard the mobility of many constituents, such as radium and trace elements. For example, high concentrations of radium in ground water have been found to correlate with greater-than-background concentrations of nitrate (Barringer and others, 1991). This pattern has been attributed to changes in ground-water quality due to leachates from fertilizer and soil additives (Kozinski and others, 1995). 
The USEPA has recently mandated or proposed the lowering of maximum contamination limits or action levels of several trace elements (lead, mercury, thallium, cadmium, beryllium, and antimony) to $10 \mu \mathrm{g} / \mathrm{L}$ or less (U.S. Environmental Protection Agency, 1991). For most of these trace elements, dissolved concentrations less than 10 $\mu \mathrm{g} / \mathrm{L}$ cannot be detected by the current, frequently used inductively coupled plasmaatomic emission spectroscopy (ICP-AES) "trace-element scans"; furthermore, improvement of sampling protocols is necessary to ensure the integrity of the sample.

The purpose of this study, conducted by the U.S. Geological Survey (USGS) in cooperation with the New Jersey Department of Environmental Protection (NJDEP), is to determine concentrations of trace elements with great accuracy at low levels $(1 \mu \mathrm{g} / \mathrm{L})$ through the use of the new analytical technique, inductively coupled plasma-mass spectrometry (ICP-MS). The USGS has developed ultra-clean sampling protocols for the collection of trace-element samples from surface water (Horowitz and others, 1994); these protocols were modified and applied to ground-water sampling to eliminate the possibility of sample contamination in the field. The new, highly sensitive analytical techniques together with the ultra-clean sampling protocols ensure the accuracy, precision, and improved representation of trace-element concentrations in ground water samples. Quantification of trace elements at the microgram-per-liter level, allows accurate establishment of a trace-element baseline to which future analyses can be compared. Shallow, young ground water commonly is used for drinking water and typically discharges to streams as baseflow. To develop stratagies to protect the quality of this resource, it is necessary to understand the spatial distribution of trace elements within the shallow aquifer systems and the water-quality changes through time.

Samples to be analyzed for low-level trace-elements were collected from public supply wells completed in the shallow, unconfined Kirkwood Cohansey aquifer system by using newly designed ultra-clean sampling protocols. Concentrations of trace elements were determined for samples collected in both agricultural and non-agricultural areas. The trace elements analyzed for are barium $(\mathrm{Ba})$, beryllium $(\mathrm{Be})$, cadmium $(\mathrm{Cd})$, chromium $(\mathrm{Cr})$, cobalt $(\mathrm{Co})$, copper $(\mathrm{Cu})$, lead $(\mathrm{Pb})$, manganese $(\mathrm{Mn})$, molybdenum $(\mathrm{Mo})$, nickel $(\mathrm{Ni})$, silver $(\mathrm{Ag})$, zinc $(\mathrm{Zn})$, antimony $(\mathrm{Sb})$, aluminum $(\mathrm{Al})$, and uranium (U). In addition, the concentration of arsenic (As) was determined to the reporting level of $1 \mu \mathrm{g} / \mathrm{L}$ by use of hydride generation; thallium ( $\mathrm{Tl}$ ) was measured to $1 \mu \mathrm{g} / \mathrm{L}$ by graphite furnace atomic absorption; and mercury $(\mathrm{Hg})$ was determined to $0.1 \mu \mathrm{g} / \mathrm{L}$ by cold-vapor atomic absorption. Accuracy and precision were monitored by the use of a commercially prepared reference standard and split samples that were analyzed at the USGS National Water Quality laboratory (NWQL) and the Rutgers University Chemistry Department laboratory (hereafter called the Rutgers laboratory). 


\section{Purpose and Scope}

This report describes the modification of surface-water low-level trace-element sampling protocols of Horowitz and others (1994) to develop a sampling protocol for lowlevel trace-element sampling of production wells. This report also lists the concentrations of trace elements measured in water from 22 public supply wells screened in the Kirkwood-Cohansey aquifer system that were sampled using the new protocol. The minimum reporting limit is 0.1 for $\mathrm{Hg}$ and using ICP-MS is $1 \mu \mathrm{g} / \mathrm{L}$ for the concentrations of the following trace elements: $\mathrm{Ba}, \mathrm{Be}, \mathrm{Cd}, \mathrm{Cr}, \mathrm{Co}, \mathrm{Cu}, \mathrm{Pb}, \mathrm{Mn}, \mathrm{Mo}, \mathrm{Ni}, \mathrm{Ag}, \mathrm{Zn}, \mathrm{Sb}, \mathrm{Al}$, and $\mathrm{U}$. Quality-assurance data which can be used to evaluate the degree to which sample contamination was minimized by the sampling protocol and laboratory performance are reported. Results of analyses performed at the USGS NWQL of three equipment blanks, one split sample, and one standard solution are included. Results of analyses performed at the Rutgers laboratory of 10 additional split samples and one equipment blank for concentrations of $\mathrm{Ba}, \mathrm{Cd}, \mathrm{Cr}, \mathrm{Cu}, \mathrm{Pb}, \mathrm{Mn}, \mathrm{Ni}, \mathrm{Zn}$, and $\mathrm{Al}$ and for the ratios of isotopes of lead are also included. Water-quality data for samples collected from 21 of the same wells during 1986-90, but analyzed with the ICP-AES technique, are presented for comparison.

\section{Description of the Study Area}

The study area encompasses most of the Kirkwood-Cohansey aquifer system (fig. 1), which is the major unconfined aquifer system in the Coastal Plain of New Jersey. It is the primary source of domestic and public drinking-water supply in most of the southwestern Coastal Plain. The study area includes parts of Atlantic, Camden, Cumberland, Gloucester, and Ocean Counties.

The Kirkwood-Cohansey aquifer system is composed of hydraulically connected sediments (predominantly fine- to medium-grained sand) of the Kirkwood Formation and the Cohansey Sand. Sands and gravels of the Bridgeton Formation locally overlie, and are in hydraulic connection with, the Cohansey Sand in southwestern New Jersey. The aquifer in southwestern New Jersey is thicker where erosional remnants of the Bridgeton Formation are present than where Bridgeton Formation deposits are absent. A thick, regionally extensive, diatomaceous marine clay, called the Alloway Clay in southwestern New Jersey, forms the basal part of the Kirkwood Formation and the basal boundary of the aquifer system (Zapecza, 1989). This formation crops out in the southwestern part of the State and marks the western boundary of the aquifer (fig. 1).

Topography is characterized by low altitude and relief, both of which decrease eastward from topographic highs (about $120 \mathrm{ft}$ above sea level) in Gloucester County, southwestern New Jersey, to sea level at the Atlantic Ocean (Lacombe and Rosman, 


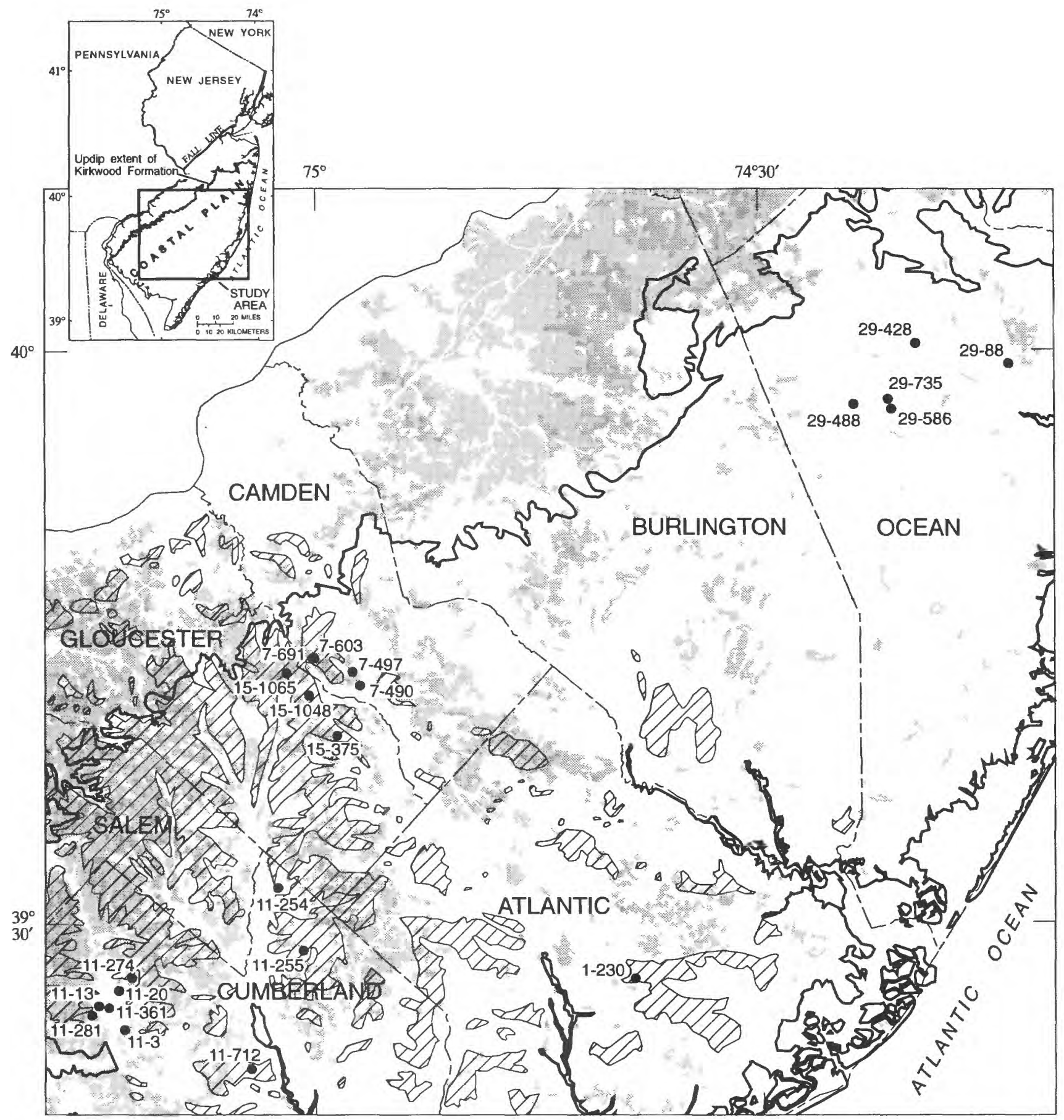

Base from U.S. Geological Survey

1:250,000 quadrangles

EXPLANATION
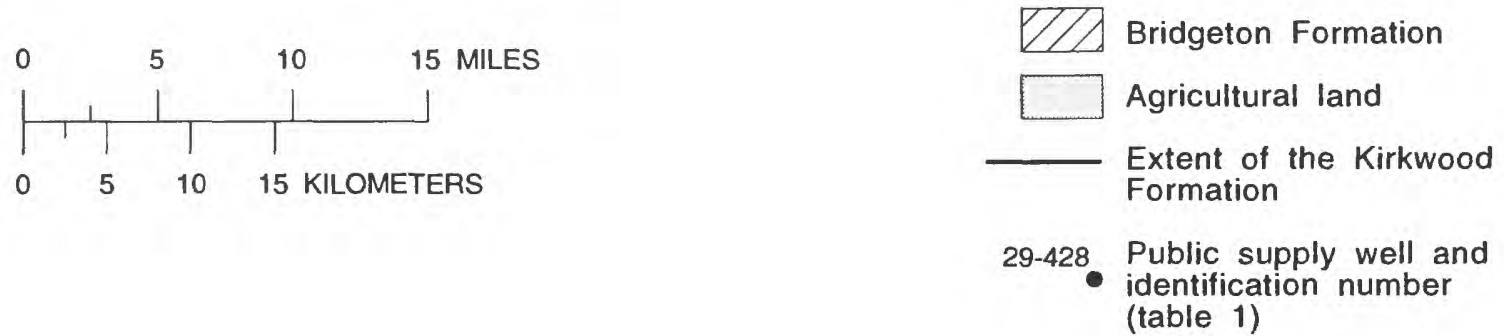

Figure 1. Location of the outcrop of the Kirkwood Formation, the extent of the KirkwoodCohansey aquifer system, the extent of the Bridgeton Formation, agricultural land, and the public supply wells sampled, Coastal Plain, New Jersey. 
1995). The Bridgeton Formation (fig. 1) crops out in topographically high areas (typically at and adjacent to the ground-water divide), and is overlain by well-drained acidic loamy, sandy, or gravelly soil that is widely used for agriculture. About 35 percent of the study area is agricultural land. The aquifer system is recharged by percolation of precipitation that falls directly on the aquifer system. Average annual precipitation in southwestern New Jersey is about $42.1 \mathrm{in}$. of which about $18.5 \mathrm{in}$. becomes ground-water recharge (Martin, in press; Lacombe and Rosman, 1995).

\section{Acknowledgments}

The authors thank Sonny Saroya, NJDEP, Bureau of Safe Drinking Water, and Karl Muessig, NJDEP, New Jersey Geological Survey, for their assistance in the selection of wells for sampling, and Eileen Murphy, NJDEP, Division of Science and Research, for serving as liaison to Rutgers University. The authors also thank the purveyors in the study area for allowing access to their wells.

\section{METHODS OF INVESTIGATION}

\section{Sampling Network}

Samples were collected during 1993 from 22 public supply wells screened in the Kirkwood-Cohansey aquifer system (fig. 1). These wells and one other well now sealed were sampled previously; samples were analyzed for radionuclides, major ions, nutrients, and trace elements. Well-construction data for these wells are provided in table 1. Analyses for trace-element concentrations in previously collected samples were performed by using the ICP-AES technique (Kozinski and others, 1995). Wells were selected in areas of agricultural land use (Atlantic, Camden, Cumberland, and Gloucester Counties) and non-agricultural land use (Ocean County). These wells are distributed throughout the areal extent of the Kirkwood-Cohansey aquifer system (fig. 1).

\section{Ultra-Clean Trace-Element Sampling Technique}

The ultra-clean trace-element sampling protocol for public supply wells, which was developed for the study, is a modification of the surface-water low-level trace-element sampling protocol developed by Horowitz and others (1994). In many instances, the only difference is the equipment that is to be cleaned and used in the sampling procedure (for example, a churn splitter that is used to composite surface-water samples is not used in ground-water sampling). The protocol is designed to minimize low-level trace-element contamination of the samples through contact with sampling equipment, by sample 
Table 1. Well-construction data for selected public supply wells screened in the Kirkwood-Cohansey aquifer system, New Jersey, 1993

[--, data not available; gal/min, gallons per minute; well locations shown in fig. 1]

\begin{tabular}{|c|c|c|c|c|c|c|c|c|c|c|}
\hline $\begin{array}{c}\text { Well } \\
\text { number }\end{array}$ & County & Municipality & $\begin{array}{c}\text { New } \\
\text { Jersey } \\
\text { permit } \\
\text { number }\end{array}$ & $\begin{array}{l}\text { Latitude } \\
\text { (degrees) }\end{array}$ & $\begin{array}{c}\text { Longitude } \\
\text { (degrees) }\end{array}$ & $\begin{array}{l}\text { Alttude } \\
\text { of land } \\
\text { surface } \\
\text { (feet } \\
\text { above sea } \\
\text { level) }\end{array}$ & $\begin{array}{c}\text { Depth } \\
\text { of well } \\
\text { (feet } \\
\text { below } \\
\text { land } \\
\text { surface) }\end{array}$ & $\begin{array}{c}\text { Top of } \\
\text { open } \\
\text { interval } \\
\text { (feet } \\
\text { below } \\
\text { land } \\
\text { surface) }\end{array}$ & $\begin{array}{l}\text { Bottom of } \\
\text { open } \\
\text { interval } \\
\text { (feet } \\
\text { below } \\
\text { land } \\
\text { surface) }\end{array}$ & $\begin{array}{l}\text { Discharge } \\
\text { (gal/min) }\end{array}$ \\
\hline $01-230$ & Atlantic & Hamilton & $36-00441$ & 392722 & 0743845 & 70 & 95.7 & 65.7 & 85.7 & 175 \\
\hline $07-490$ & Camden & Winslow & $31-05543$ & 394248 & 0745710 & 115 & 113 & 72 & 103 & 1,000 \\
\hline 07.497 & Camden & Winslow & $31-05534$ & 394332 & 0745740 & 125 & 101 & 64 & 90 & 1,000 \\
\hline $07-603$ & Camden & Gloucester & $31-16697$ & 394414 & 0750016 & 140 & 120 & 100 & 120 & 503 \\
\hline $07-691$ & Camden & Gloucester & $31-24727$ & 394414 & 0750015 & 160 & 80 & 60.2 & 75 & 305 \\
\hline $11-3$ & Cumberland & Bridgeton & $54-00003$ & 392437 & 0751305 & 43 & 104 & 84 & 104 & 776 \\
\hline $11-13$ & Cumberland & Bridgeton & $34-00598$ & 392552 & 0751450 & 65 & 117 & 76. & 117 & 525 \\
\hline $11-20$ & Cumberland & Bridgeton & $54-00001$ & 392641 & 0751329 & 80 & 111 & 91 & 111 & 510 \\
\hline $11-254$ & Cumberland & Vineland & $35-05227$ & 393208 & 0750245 & 90 & 160 & 130 & 160 & 1.030 \\
\hline $11-255$ & Cumberland & Vineland & $35-00869$ & 392850 & 0750103 & 90 & 174 & 140 & 170 & 100 \\
\hline $11-274$ & Cumberland & Bridgeton & 34-01195 & 392722 & 0751235 & 100 & 110 & 70 & 110 & 439 \\
\hline${ }^{1} 11-278$ & Cumberland & Millville & $35-00862$ & 392238 & 0750420 & 70 & 191 & 161 & 191 & -- \\
\hline $11-281$ & Cumberland & Hopewell & $34-01194$ & 392523 & 0751519 & 75 & 146 & 86 & 146 & 732 \\
\hline $11-361$ & Cumberland & Bridgeton & $34-01945$ & 392538 & 0751434 & 53 & 90 & 75 & 90 & 400 \\
\hline $11-712$ & Cumberland & Millville & $35-12630$ & 392235 & 0750432 & 75 & 222 & 162 & 217 & 1,280 \\
\hline 15- 375 & Gloucester & Monroe & $31-14080$ & 394010 & 0745845 & 148 & 147 & 118 & 147 & 805 \\
\hline $15-1048$ & Gloucester & Monroe & $31-27529$ & 394217 & 0750039 & 162 & 144 & 100 & 141 & 492 \\
\hline $15-1065$ & Gloucester & Washington & $31-28782$ & 394327 & 0750210 & 152 & 85 & 59.2 & 85 & 1,020 \\
\hline $29-88$ & Ocean & Dover & $33-01147$ & 395933 & 0741312 & 40 & 86 & 66 & 86 & 503 \\
\hline 29- 428 & Ocean & Lakehurst & $29-01088$ & 400039 & 0741930 & 64 & 36 & 26 & 36 & 100 \\
\hline 29- 488 & Ocean & Manchester & $28-06885$ & 395729 & 0742343 & 150 & 143 & 123 & 143 & 300 \\
\hline 29. 586 & Ocean & Manchester & $32-01985$ & 395714 & 0742112 & 100 & 90.1 & 61.1 & 81.1 & 501 \\
\hline 29. 735 & Ocean & Manchester & $32-02893$ & 395745 & 0742124 & 167 & 173 & 148 & 173 & 754 \\
\hline
\end{tabular}

${ }^{1}$ Well sealed in 1993 
handling, and with airborne dust particles. Minor contamination of water samples from public supply wells by metallic casings, tubing, fittings, and solder cannot be avoided by using the ultra-clean sampling; therefore, $1 \mu \mathrm{g} / \mathrm{L}$ was maintained as the reporting limit in this study for all trace elements except $\mathrm{Hg}$. Reporting limits less than $1 \mu \mathrm{g} / \mathrm{L}$ are feasible for polyvinyl chloride (PVC)-cased observation wells, in which low-level contamination can be avoided by careful sample collection in the absence of metallic casing, tubing, fittings, and solder. Turbidity was measured to determine the amount of suspended material in the water.

Five quality-assurance/quality-control samples consisting of three equipment blanks, one split sample, and one standard solution were analyzed at the NWQL to evaluate the presence of contamination and the precision and accuracy of the laboratory analyses. The equipment blanks and the split sample were collected randomly throughout the sampling period. To avoid any sampling or seasonal bias, the same personnel collected all the ground-water samples over a short interval (September 1993).

\section{Sampling-Equipment Cleaning Procedures}

Directions for the method used to clean sampling equipment during this study are given below, and consists of four steps; deionized water rinse, soap-solution rinse, nitricacid rinse, and final deionized water rinse.

1. Put on powder-free latex gloves, apron, and safety glasses prior to cleaning equipment. Place $50-\mathrm{ft}$ lengths of polyethylene tubing (3/8-in. outside diameter) and PVC hose barbs, hose connectors, and plastic clamps in a pre-soap and acid-washed designated tray filled with deionized (DI) water. (White or clear acid-resistant plastics (polyethylene or polypropylene) were used. Colored plastics were avoided because the metals used in the pigments could be leached by the cleaning acid.) Rinse each piece of equipment with DI water three times. Force DI water through the tubing for 10 minutes by using a peristaltic pump.

2. After the third rinse with DI water, fill tray with $8 \mathrm{~L}$ of DI water and 2 to $3 \mathrm{~mL}$ of phosphate-free soap. Allow tubing and hose barbs, connectors, and plastic clamps to soak in soap solution for 10 minutes in the tray. Scrub hose barbs, connectors, clamps, and outside of tubing with a non-metallic brush. Force soapy solution through tubing for 15 minutes by using a peristaltic pump. Rinse all hose barbs, connectors, and clamps three times with DI water, until no signs of soap remain. Force DI water through tubing for 10 minutes by using a peristaltic pump, until no signs of soap remain. Place polyethylene tubing, hose barbs, connectors, and clamps in a designated pre-cleaned second tray. Change gloves. 
3. Make a 5-percent nitric acid solution with laboratory grade acid ( $8 \mathrm{~L}$ of DI water to $500 \mathrm{~mL} \mathrm{HNO}_{3}$ ) in the tray. (Nitric acid was used instead of hydrochloric acid because nitric acid has stronger oxidizing properties, which are essential for removing the sorbed trace elements. Nitric acid also tends to be free of trace elements, whereas hydrochloric acid is not. Nitric acid is a potential source of nitrate contamination in the sampling equipment; however, because samples were not analyzed for nutrients as part of this investigation, nitrate contamination was not a concern.) Force the acid solution through the tubing for 20 minutes, by using a peristaltic pump, to remove any trace elements that could be sorbed to the surface of the tubing. Meanwhile, soak the hose barbs, connectors, and clamps in the acid solution for 20 minutes. Rinse all hose barbs, connectors, and clamps three times with DI water. Force DI water through tubing for 10 minutes by using a peristaltic pump.

4. Allow all clean tubing and other clean equipment to air dry, then store in plastic bags marked with the date of cleaning. To prevent contamination from bacterial growth, use tubing within 5 days of cleaning.

\section{Ultra-Clean Sample-Collection Procedures}

A vehicle dedicated to low-level trace-element sampling was used. This van had not been used previously for any water-quality-sampling field work and, therefore, was not contaminated with mercuric chloride, which had been used as a preservative for nutrient samples. The van had been outfitted with a wooden floor and formica benchtop.

Nitric acid and potassium dichromate preservation ampules, clean tubing, latex gloves, shipping and ziplock storage bags, and polyethelyne pre-acid-washed sample bottles were placed in plastic bags and were stored in shipping boxes in the rear of the van. A clean shipping cooler used only for low-level trace-element sampling and ice were available for chilling and storing water samples.

A sampling routine was established to ensure the integrity of the samples. Tasks were divided between two people: One person, designated "dirty hands," was responsible for those tasks that could introduce contamination into the samples (working with the pump, monitoring meters) and, therefore, could not come in contact with the samples, the second person, designated "clean hands," was responsible for sample collection, handling, and preservation.

Upon arrival at the sampling site, the "clean hands" person, wearing latex gloves, prepared the van for sampling. A disposable polypropylene tarp was laid over the plywood floor. Portable glove-bag chamber frames--one large glove-bag chamber to be used for sample filtration and a smaller glove-bag chamber to be used for sample 
preservation--were assembled. The chamber frames were made of PVC 1/4-in. pipes that were pre-cleaned in a dishwasher, with a commercial dishwasher soap. The pipes fit together to make a square frame (A.J. Horowitz, U.S. Geological Survey, written commun., 1993). The chambers were completed by suspending large polyethylene bags from the frames to create a dust-free sample-collection and -preservation area. A separate preservation chamber was constructed for each sample preservative.

Sample bottles were pre-labeled and placed inside the large filtration chamber. A disposable 0.45 -micron polysulfone-filter-medium tortuous-path capsule filter with a filtration area of $7.9 \mathrm{in}^{2}$ was used instead of a reusable plate filter; it was also placed into the filtration chamber. Disposable filters were used to avoid sample cross-contamination. Ampules of potassium dichromate (for mercury samples) were placed inside one preservation chamber; ampules of ultra-pure nitric acid (for other trace-element samples) were placed in the second.

The "dirty hands" person monitored $\mathrm{pH}$, temperature, specific conductance, and dissolved-oxygen concentration, as described by Wood (1976). Samples were collected after meter readings stablized (three consecutive readings, at 5-minute intervals, that did not vary by more than 5 percent). When high-yielding public supply wells are sampled, the volume of water needed for adequate well purging is not a concern. Several thousand gallons of water were discharged from the wells prior to sample collection. Samples were collected by attaching a clean piece of tubing to a "raw-water" port on the wellhead. The polyethelyne sample tubing was fed into the sampling van through the window, was cut with non-metallic scissors, and was fed through a small hole punched in the back of the filtration-chamber bag. The flow of water into the sampling van was regulated at the port by the "dirty hands" person.

Sample bottles were filled in a specific sequence as described by Horowitz and others (1994): unfiltered, unpreserved (turbidity) in polyethelyne bottles; filtered, potassium dichromate- preserved (mercury) in acid-washed glass bottles; and filtered, ultra-pure nitric acid-preserved (other trace elements) in acid-washed polyethelyne bottles. After the unfiltered, unpreserved samples were collected, the flow of water into the sampling line was stopped to facilitate connection of the disposable capsule filter. About 1L of native water was used to condition the filter (Horowitz and others, 1994). The acid-rinsed glass and polyethelyne bottles were rinsed three times with filtered water prior to sample collection.

When all the samples had been collected, the "clean hands" person moved the sample bottles into the appropriate preservation chambers. Mercury samples were preserved with potassium dichromate in the first chamber, and the trace-element samples 
were preserved with ultra-pure nitric acid in the second chamber. Gloves were changed to avoid cross-contamination of samples each time a new preservation chamber was used. After all the samples were preserved, the bottles were placed in plastic bags and chilled.

\section{Procedures for Collecting Equipment Blanks and Split Samples}

A variety of samples were collected for quality assurance and quality control during the sampling period. These samples included splits, equipment blanks, and one standard solution. Sample splits provided quality control, and equipment blanks and the spiked sample were submitted as quality assurance. Sample splits were collected for about 55 percent of the samples (11 split samples). To compare laboratory results, 10 of those splits were submitted to the Rutgers laboratory for ICP-MS trace-element analysis. One split sample was submitted to the NWQL. Equipment blanks constituted 14 percent of the sample load ( 3 field blanks). One of the equipment blanks was split and sent to the Rutgers laboratory for analysis.

Split samples were prepared in the filtration chamber in the field. For samples to be analyzed for trace elements (except mercury), two 1-L acid-rinsed polyethelyne bottles were each rinsed three times with native filtered water. The first $1-\mathrm{L}$ bottle was filled with a water sample. Water from the first bottle was poured into the second bottle. One-half of the contents of the second bottle was poured back into the first bottle. The 1-L sample of water was split into two 500-mL samples that had had contact with both sample bottles. Each split sample to be analyzed for trace elements was placed into the acid-preservation chamber, and $1 \mathrm{~mL}$ of ultra-pure nitric acid was added. Split samples to be analyzed for mercury were collected by using the same technique as that used to collect the split samples to be analyzed for trace elements, except that two $250-\mathrm{mL}$ acid-washed glass bottles were used.

Equipment-blank samples were collected from a pre-cleaned polyethylene pipette jar (standpipe); a peristaltic pump was used to pump pre-analyzed, inorganic blank water through the sample tubing into a sample bottle. All the equipment blanks were collected inside a glove-bag filtration chamber inside the sampling vehicle. One set of equipment blanks was collected and split; one set of split samples was sent to the Rutgers laboratory and the other was sent to the NWQL for analysis.

\section{Sample Analysis}

Turbidity was determined by nephelometry (Fishman and Friedman, 1989) in the laboratory. Alkalinity was determined by incremental titration in the laboratory (Fishman and Friedman, 1989). Low concentrations $(1 \mu \mathrm{g} / \mathrm{L})$ of trace elements $(\mathrm{Ba}, \mathrm{Al}, \mathrm{Ag}, \mathrm{Be}, \mathrm{Cd}$, $\mathrm{Co}, \mathrm{Cr}, \mathrm{Cu}, \mathrm{Mn}, \mathrm{Mo}, \mathrm{Ni}, \mathrm{Pb}, \mathrm{Sb}, \mathrm{U}$, and $\mathrm{Zn}$ ) in the samples were determined by ICP-MS. 
Flameless atomic absorption (AA) hydride-generation techniques were used to determine the concentration of arsenic (Fishman and Friedman, 1989). The USEPA-approved coldvapor flameless AA technique was used to determine the concentration of mercury (U.S. Environmental Protection Agency, 1979, p. 245). Graphite-furnace AA was used to determine the concentration of thallium (Fishman and Friedman, 1989). The analytical technique and the minimum reporting limit for each analyte are given in table 2.

The water-quality data presented in table 3 (at end of report) were determined from samples collected from the well network during 1986-90. Well 11-278 was sealed in 1993, prior to sampling, and well 11-712 was drilled by the purveyor in a similar location and to a similar depth as a replacement well for 11-278. Dissolved-oxygen concentration, $\mathrm{pH}$, specific conductance, and temperature of samples collected during 1986-90 were measured in the field according to methods described by Wood (1976). All samples were analyzed at the NWQL. Alkalinity (as calcium carbonate) was determined in the laboratory by incremental titration. Concentrations of major cations and trace elements were determined by use of atomic emisson spectroscopy with an inductively coupled argon radio frequency plasma torch (ICP-AES). Concentrations of nutrients were determined by use of colorometric techniques outlined by Fishman and Friedman (1985); the method in which nitrogen (as nitrate plus nitrite) was used was equivalent to accepted USEPA methods (Fishman and Friedman, 1985; U.S. Environmental Protection Agency, 1979). Previously collected trace-element data from these wells were included in this report (table 3) to illustrate the benefit of determining trace-element concentrations at levels significantly lower than those achieved by the ICP-AES "metal scan" technique. Concentrations of trace elements such as $\mathrm{Pb}, \mathrm{Cu}, \mathrm{Cr}$, and $\mathrm{Cd}$, for which drinking-water regulations exist, were all previously reported as less than the detection limit of the ICPAES technique. With the introduction of ICP-MS analyses, the actual concentrations of these constituents could be determined.

Determination of the concentrations of the 15 selected elements by ICP-MS required only a few milliliters of sample water. Six minutes were required to complete a sample-analysis cycle, which consists of sample uptake, three replicate mass-spectrometer integrations, and an equipment rinse with deionized water for each sample. A calibration curve was generated by using a calibration blank and multi-element standard solutions of known concentrations. Average short-term precision reported by the NWQL in its own internal quality-assurance program is 1.7 percent relative standard deviation for element concentrations ranging from 25 to $50 \mu \mathrm{g} / \mathrm{L}$ (Faires, 1993). Internal standard spikes are added to all blanks, calibration standards, samples, and quality-control samples to correct for instrumental drift and suppression or enhancement of analyte signals resulting from matrix effects. Several types of physical, chemical, or spectral interferences are 
Table 2. Analytical technique, minimum reporting limit, minimum limit of detection, and precision for trace elements in water samples from the Kirkwood-Cohansey aquifer system. New Jersey, 1993

[ $\mu \mathrm{g} / \mathrm{L}$, micrograms per liter; 1CP-MS, inductively coupled plasma-mass spectrometry; AA, atomic adsorption; 1CP-AES, inductively coupled plasma-atomic emission spectroscopy; DCP-AES, direct current plasma-atomic emission spectroscopy; -- , data not available]

\begin{tabular}{|c|c|c|c|c|}
\hline Trace element & Anaiyticai technique $^{1}$ & $\begin{array}{c}\text { Minimum } \\
\text { reporting } \\
\text { limit } \\
(\mu \mathrm{g} / L)\end{array}$ & $\begin{array}{c}\text { Minimum } \\
\text { detection } \\
\text { limit } \\
(\mu \mathrm{g} / \mathrm{L})\end{array}$ & $\begin{array}{c}\text { Relative } \\
\text { standard } \\
\text { deviation at a } \\
\text { concentration } \\
\text { of } 1 \mu \mathrm{g} / \mathrm{L} \\
\text { (percent) }\end{array}$ \\
\hline Aluminum $^{3}$ & ICP-MS & 1 & 1 & 140 \\
\hline Antimony & ICP-MS & 1 & .26 & 20 \\
\hline Barium & ICP-MS & 1 & .12 & 40 \\
\hline Beryllium & ICP-MS & 1 & .07 & 30 \\
\hline Cadmium & ICP-MS & 1 & .16 & 40 \\
\hline Chromium & 1CP-MS & 1 & .16 & 30 \\
\hline Cobalt & ICP-MS & 1 & .07 & 30 \\
\hline Copper $^{3}$ & ICP-MS & 1 & .10 & 40 \\
\hline Lead $^{3}$ & ICP-MS & 1 & .18 & 30 \\
\hline Manganese & ICP-MS & 1 & .18 & 20 \\
\hline Molybdenum $^{3}$ & ICP-MS & 1 & .22 & 30 \\
\hline Nickel $^{3}$ & ICP-MS & 1 & .19 & 30 \\
\hline Silver & ICP-MS & 1 & .07 & 40 \\
\hline Uranium & ICP-MS & 1 & .16 & 20 \\
\hline Zinc & ICP-MS & 1 & .22 & 30 \\
\hline Arsenic & Flameless AA (hydride) & 1 & 1 & -- \\
\hline Mercury & Cold vapor flameless AA (hydride) & 0.1 & .1 & -- \\
\hline Thallium & Graphite furnace AA & 1 & .1 & - \\
\hline
\end{tabular}

\footnotetext{
${ }^{1}$ Analyses done by ICP-MS in this study were completed by using ICP-AES or DCP-AES in 1986-90.

${ }^{2}$ Relative standard deviation is less than or equal to 10 percent at concentrations of $5 \mu \mathrm{g} / \mathrm{L}$ for all elements analyzed by ICP-MS, except aluminum. for which the value is about 100 percent.

${ }^{3}$ Minimum reporting limit for this element is lower by a factor of 10 when ICP-MS is used than when ICP-AFS or DCP-AES is used.
} 
fully described and documented for ICP-MS techniques (Date and Gray, 1989). The trace-element analytes determined in this study have at least one isotope, which is free of such potential interference, that can be used for quantitative analysis.

The average method detection limit for the 15 trace-element analytes determined by using ICP-MS was $0.22 \mu \mathrm{g} / \mathrm{L}$ (Faires, 1993). The reporting limit for routine analysis of samples from the public supply wells was $1 \mu \mathrm{g} / \mathrm{L}$ for each element. The purpose of using the $1-\mu \mathrm{g} / \mathrm{L}$ reporting limit rather than the $0.22-\mu \mathrm{g} / \mathrm{L}$ detection limit is twofold: (1) to minimize the problems associated with possible field and laboratory contamination at the submicrogram-per-liter level and (2) to ensure a high degree of confidence in analytical results from the routine mode of operation for analysis of samples collected from an environment (public supply wells with iron casing, metal pump, copper tubing, brass fittings, and solder of various metal compositions) where low-level contamination with metals is highly probable.

\section{Quality Assurance}

Equipment blanks and duplicates were closely monitored to ensure the integrity of the samples was not compromised during the field sampling process. The accuracy of the ICP-MS analytical method was verified by the laboratory by means of analyses of internal standard-reference-water samples with certified or most probable values for the concentrations of the dissolved analytes. This accuracy was verified for the study by submitting a commercially-prepared reference standard sample containing known amounts of trace elements to the laboratory for analysis and comparing the analytically determined results to the known values.

\section{CONCENTRATIONS OF TRACE ELEMENTS}

Separate samples were collected for turbidity analyses because suspended particles and mobile colloid phases affect the transport of trace elements, especially $\mathrm{Pb}, \mathrm{Cr}, \mathrm{Cu}$, and $\mathrm{Ni}$ (Backhus and others, 1993). Turbidity values for the samples generally were equal to or less than 1 NTU, except for samples from wells 01-230 and 29-428, which had turbidities of 20 and 8.7 NTU's, respectively. In 1993, well 01-230 was no longer being used by the purveyor and had not been pumped for many months prior to sampling, whereas well 29-428 was used intermittently by the purveyor. Backhus and others (1993) suggest that ground-water turbidity should be monitored to determine when a well has been adequately purged for sampling, especially in studies of trace elements. Trace elements tend to sorb to particle surfaces. Field monitoring of turbidity can ensure the collection of representative samples with reproducible trace-element concentrations by 
allowing sample collection to be delayed until the number of suspended particles is constant. Trace-element data collected from the public supply wells theoretically should be reproducible because the concentration of suspended colloids and particles is low.

Results of the trace-element analysis (table 4 at end of report) indicate that 5 of the 18 trace elements measured-- $\mathrm{Co}, \mathrm{Cu}, \mathrm{Pb}, \mathrm{Hg}$, and $\mathrm{Ni}$--typically were detected in low concentrations ranging from $<0.1$ to $29 \mu \mathrm{g} / \mathrm{L}$ (table 5) in most of the samples from the 22 wells; and 4 trace elements--Al, $\mathrm{Ba}, \mathrm{Mn}$ and $\mathrm{Zn}$--were detected in high concentrations (30 to $710 \mu \mathrm{g} / \mathrm{L}$ for $\mathrm{Al}$, and 4.0 to $180 \mu \mathrm{g} / \mathrm{L}$ for $\mathrm{Ba}, \mathrm{Mn}$, and $\mathrm{Zn}$ ) (table 5). Concentrations of $\mathrm{As}, \mathrm{Be}, \mathrm{Cd}, \mathrm{Cr}, \mathrm{Sb}, \mathrm{Mo}, \mathrm{Tl}, \mathrm{Ag}$, and $\mathrm{U}$ were less than the detection limit $(1.0 \mu \mathrm{g} / \mathrm{L})$ in samples from all the wells (table 4).

The concentration of $\mathrm{Pb}$ in one sample (well 11-13) exceeded the USEPA action level $(15 \mu \mathrm{g} / \mathrm{L})$ (U.S. Environmental Protection Agency, 1990) and in two other samples (wells 29-735 and 11-254) approached the action level (12 and $11 \mu \mathrm{g} / \mathrm{L}$, respectively). The action level is a concentration set by the USEPA in lieu of a drinking-water maximum contaminant level (MCL). This level requires the purveyor, in addition to primary treatment (flocculant removal, bacterial control, and $\mathrm{pH}$ balance), to further treat the water by adding corrosion-controlling chemicals before distributing it to the customers. The proposed MCL goal for $\mathrm{Pb}$ in drinking water is zero. The concentration of $\mathrm{Hg}$ in the sample from well 29-428 $(1.1 \mu \mathrm{g} / \mathrm{L})$ approached the USEPA MCL of $2 \mu \mathrm{g} / \mathrm{L}$, whereas samples from five other wells contained $\mathrm{Hg}$ in concentrations of $0.1 \mu \mathrm{g} / \mathrm{L}$ (the detection level) or $0.2 \mu \mathrm{g} / \mathrm{L}$. The concentrations in samples from nine wells exceeded the USEPA secondary maximum contaminant level (SMCL) for $\mathrm{Al}(200 \mu \mathrm{g} / \mathrm{L})$, and concentrations in two water samples (wells 07-691 and 11-254) exceeded the SMCL for Mn $(50 \mu \mathrm{g} / \mathrm{L}$ ) (U.S. Environmental Protection Agency, 1990).

Results of analyses of equipment-blank samples performed by using ICP-MS indicate that samples collected during 1993 by using the ultra-clean sampling technique were free of microgram-per-liter-level trace-element contamination (table 6).

Concentrations of all elements except zinc in the equipment-blank samples were less than the reporting limit of $1 \mu \mathrm{g} / \mathrm{L}$ for ICP-MS. One blank sample contained a concentration of $\mathrm{Zn}$ of $1 \mu \mathrm{g} / \mathrm{L}$, indicating that $\mathrm{Zn}$ contamination at the $1-$ to $2-\mu \mathrm{g} / \mathrm{L}$ level can occur randomly. Faires (1993) reported persistent problems with low-level Zn contamination in the laboratory. The equipment blank submitted to the Rutgers laboratory also was free of microgram-per-liter-level trace-element contamination (table 6) for the elements analyzed. Zinc was the only element with a concentration greater than $0.2 \mu \mathrm{g} / \mathrm{L}(0.2 \mu \mathrm{g} / \mathrm{L}$ detection limit at the Rutgers laboratory). 
Table 5. Statistical summary and distribution of selected trace elements, $\mathrm{pH}$, and turbidity in samples from selected public supply wells in the Kirkwood-Cohansey aquifer system, New Jersey, 1993

$[<$, less than $]$

\begin{tabular}{|c|c|c|c|c|c|c|c|c|}
\hline $\begin{array}{c}\text { Trace } \\
\text { element or } \\
\text { physical } \\
\text { property }\end{array}$ & $\begin{array}{l}\text { Number } \\
\text { of values }\end{array}$ & Mean & $\begin{array}{l}\text { Standard } \\
\text { deviation }\end{array}$ & Median & Minimum & Maximum & $\begin{array}{c}\text { 25th } \\
\text { percentile }\end{array}$ & $\begin{array}{c}\text { 75th } \\
\text { percentile }\end{array}$ \\
\hline Turbidity & 20 & 1.74 & 4.69 & 0.2 & 0.10 & 20.0 & 0.2 & 0.6 \\
\hline $\mathrm{pH}$ & 21 & 4.74 & .33 & 4.7 & 4.20 & 5.40 & 4.5 & 5 \\
\hline Barium & 22 & 62.63 & 40.29 & 53 & 20.0 & 180.0 & 30 & 78 \\
\hline Cobalt & 22 & 1.75 & 1.70 & 1 & $<1$ & 8.0 & $<1$ & 2 \\
\hline Copper & 22 & 12.93 & 8.14 & 12 & $<1$ & 29.0 & 8 & 17 \\
\hline Lead & 22 & 3.79 & 4.53 & 1.5 & $<1$ & 16.0 & $<1$ & 6 \\
\hline Manganese & 22 & 23.72 & 18.08 & 18.5 & 4.0 & 82.0 & 13 & 27 \\
\hline Nickel & 22 & 2.31 & 1.80 & 2 & $<1$ & 8.0 & 1 & 3 \\
\hline Zinc & 22 & 32.45 & 35.23 & 19.5 & 5.0 & 130.0 & 8 & 38 \\
\hline Aluminum & 22 & 194.54 & 180.91 & 100 & 30.0 & 710.0 & 80 & 260 \\
\hline Mercury & 22 & .12 & .22 & $<0.1$ & $<0.1$ & 1.1 & $<0.1$ & .1 \\
\hline
\end{tabular}


Analysis of the commercially-prepared National Institute of Standards (NIST) standard solution CRM-390127 by ICP-MS at the NWQL produced values that were in agreement with the known concentrations of the elements in the solution. The standard sample was submitted as a blind quality-control sample. The relative percent difference between most of the analytically determined concentrations and the known values was 10 percent or less, except for concentrations of $\mathrm{Ba}, \mathrm{Cd}$, and $\mathrm{Tl}$ which differed from the known values by $12.8,28$, and 18.2 percent, respectively (table 7 ). The analytically determined concentrations of $\mathrm{Cd}$ and $\mathrm{Tl}$ were 0.5 to $1.0 \mu \mathrm{g} / \mathrm{L}$ higher than the known values, whereas the measured concentration of $\mathrm{Ba}$ was $0.5 \mu \mathrm{g} / \mathrm{L}$ lower than the known value. For 6 of the 10 elements $(\mathrm{Ba}, \mathrm{Co}, \mathrm{Pb}, \mathrm{Mn}, \mathrm{Ni}$, and $\mathrm{Zn}$ ) for which the analytically determined concentration did not match the known value, the analytically determined concentration was lower than the known value (table 6). The analytically determined concentrations of $\mathrm{As}, \mathrm{Cd}, \mathrm{Tl}$, and $\mathrm{Al}$ were higher than the known values.

Results of analysis of the split sample collected from well 29-428 and analyzed at the NWQL agreed closely with results of analysis of the sample (table 4). All but one of the values differed by 5 percent or less; the difference in the concentration of Al between the sample and the split sample was 10 percent. This difference is attributed to inherent difficulties in analyzing for aluminum by using ICP-MS (Faires, 1993).

Constituent concentrations in the 10 split samples analyzed by using ICP-MS at the Rutgers laboratory showed good agreement (within 10 percent) (table 4) with the NWQL data for most elements, indicating that the ICP-MS analyses were accurate and precise and are reproducible between laboratories. Cd concentrations determined at the two laboratories could not be compared because the results from the NWQL were all below the reporting limit (table 4). Apparent low biases exist in the Rutgers laboratory data for $\mathrm{Ba}$ ( -4.6 to -18 percent difference), Mn ( -0.5 to -6 percent difference), and $\mathrm{Zn}$ (fig. $2 \mathrm{a}$ ), compared to the NWQL data for these elements (table 7). Cr also showed an apparent low bias at the Rutgers laboratory. All the concentrations of Cr reported by the NWQL were below the reporting limit; the results from the Rutgers laboratory, however, indicated that all $\mathrm{Cr}$ concentrations were non-detectable (reported as zero) (table 4). Nickel is the only trace element that had an apparent high bias (fig. 2b) at the Rutgers laboratory, compared to the NWQL data. Isotopes of $\mathrm{Pb}$ also were analyzed at the Rutgers laboratory using ICP-MS. The ratios of ${ }^{206} \mathrm{~Pb}$ to ${ }^{207} \mathrm{~Pb}$ for ten of the public supply wells ranged from 1.1 to 1.27 (table 4). 
Table 6. Results of analyses for concentrations of constituents in quality-assurance/quality-control equipment blanks and reference standard for water samples collected during 1993, New Jersey

[ $\mu \mathrm{g} / \mathrm{L}$, microgram per liter; <, less than; --, data not available; NA, not analyzed]

\begin{tabular}{cccccc}
\hline Sample & Date & Time & $\begin{array}{c}\text { Arsenic, } \\
\text { dissolved } \\
(\mathbf{m g} / \mathbf{L} \\
\text { as As) }\end{array}$ & $\begin{array}{c}\text { Barium, } \\
\text { dissolved } \\
(\mathbf{m g} / \mathbf{L} \\
\text { as Ba) }\end{array}$ & $\begin{array}{c}\text { Beryllium, } \\
\text { dissolved } \\
(\mathbf{m g} / \mathbf{L} \\
\text { as Be) }\end{array}$ \\
\hline${ }^{1}$ Blank I & $09-(03-93$ & 1345 & $<1$ & $<1$ & $<\mathrm{I}$ \\
${ }^{2}$ Blank 2 & $09-03-93$ & 1345 & $\mathrm{NA}$ & .02 & $\mathrm{NA}$ \\
${ }^{1}$ Blank 3 & $09-08-93$ & 1240 & $<1$ & $<1$ & $<1$ \\
${ }^{\text {'Blank 4 }}$ & $09-28-93$ & 1900 & $<1$ & $<1$ & $<\mathrm{I}$ \\
${ }^{3}$ Standard & $09-09-93$ & 1445 & $21(20)$ & $\mathrm{I} 1(12.5)$ & $5(5)$ \\
\hline
\end{tabular}

\begin{tabular}{|c|c|c|c|c|c|c|c|c|}
\hline Sample & Date & $\begin{array}{c}\text { Cadmi um, } \\
\text { dissolved } \\
(\mu \mathrm{g} / \mathrm{L} \\
\text { as Cd })\end{array}$ & $\begin{array}{c}\text { Chromlum, } \\
\text { dissolved } \\
(\mu \mathrm{g} / \mathrm{L} \\
\text { as } \mathrm{Cr})\end{array}$ & $\begin{array}{c}\text { Cobalt, } \\
\text { dissolved } \\
(\mu \mathrm{g} / \mathrm{L} \\
\text { as Co })\end{array}$ & $\begin{array}{c}\text { Copper, } \\
\text { dissolved } \\
(\mu \mathrm{g} / \mathbf{L} \\
\text { as } \mathrm{Cu})\end{array}$ & $\begin{array}{c}\text { Lead, } \\
\text { dissolved } \\
(\mu \mathrm{g} / \mathrm{L} \\
\text { as } \mathbf{P b})\end{array}$ & $\begin{array}{c}\text { Manganese, } \\
\text { dissolved } \\
(\mu \mathrm{g} / \mathbf{L} \\
\text { as } M \mathbf{n})\end{array}$ & $\begin{array}{c}\text { Thallium, } \\
\text { dissolved } \\
(\mu \mathrm{g} / \mathrm{L} \\
\text { as } \mathrm{TI})\end{array}$ \\
\hline Blank 1 & 09-03-93 & $<1.0$ & $<1$ & $<1$ & $<1$ & $<1$ & $<1$ & $<1$ \\
\hline Blank 2 & $09-03-93$ & .01 & 0 & NA & 0 & .07 & NA & NA \\
\hline Blank 3 & $09-08-93$ & $<1.0$ & $<1$ & $<1$ & $<1$ & $<1$ & $<1$ & $<1$ \\
\hline Blank 4 & $09-28-93$ & $<1.0$ & $<1$ & $<\mathrm{I}$ & $<1$ & $<1$ & $<1$ & $<1$ \\
\hline Standard & $09-09-93$ & $4.0(3.0)$ & $5(5)$ & $6(6.25)$ & $5(5)$ & $8(8.75)$ & $8(8.75)$ & $3(2.5)$ \\
\hline
\end{tabular}

\begin{tabular}{|c|c|c|c|c|c|c|c|c|c|}
\hline Sample & Date & $\begin{array}{c}\text { Molybdenum, } \\
\text { dissolved } \\
(\mu \mathrm{g} / \mathrm{L} \\
\text { as Mo) }\end{array}$ & $\begin{array}{c}\text { Nickel, } \\
\text { dissolved } \\
(\mu \mathrm{g} / \mathrm{L} \\
\text { as NI) }\end{array}$ & $\begin{array}{c}\text { Silver, } \\
\text { dissolved } \\
(\mu \mathrm{g} / \mathbf{L} \\
\text { as } \mathbf{A g})\end{array}$ & $\begin{array}{c}\text { ZInc, } \\
\text { dissolved } \\
(\mu \mathrm{g} / \mathbf{L} \\
\text { as } \mathrm{Zn})\end{array}$ & $\begin{array}{c}\text { Antimony, } \\
\text { dissolved } \\
(\mu \mathrm{g} / \mathrm{L} \\
\text { as Sb) }\end{array}$ & $\begin{array}{c}\text { Aluminum, } \\
\text { dissolved } \\
(\mu \mathrm{g} / \mathrm{L} \\
\text { as Al) }\end{array}$ & $\begin{array}{c}\text { Mercury, } \\
\text { dissolved } \\
(\mu \mathrm{g} / \mathrm{L} \\
\text { as } \mathbf{H g})\end{array}$ & $\begin{array}{c}\text { Uranium, } \\
\text { natural, } \\
\text { dissolved } \\
(\mu \mathrm{g} / \mathrm{L} \\
\text { as } \mathrm{U})\end{array}$ \\
\hline Blank 1 & $09-03-93$ & $<1.0$ & $<1$ & $<1.0$ & $<1$ & $<1$ & $<1$ & $<.1$ & $<1.0$ \\
\hline Blank 4 & $09-28-93$ & $<1.0$ & $<1$ & $<1.0$ & 1 & $<1$ & $<1$ & $<.1$ & $<1.0$ \\
\hline Standard & $09-09-93$ & $25(25)$ & $14(15)$ & $<1.0(<0.1)$ & $16(17.5)$ & $<1(--)$ & $30(28.75)$ & $--(--)$ & $<1.0(-)$ \\
\hline
\end{tabular}

${ }^{1}$ Equipment blanks analyzed at the U.S. Geological Survey National Water Quality laboratory

${ }^{2}$ Equipment blanks analyzed at the Rutgers University Chemistry Department laboratory

${ }^{3}$ Known values obtained from the National Institute of Standards and Technology given in parentheses 
Table 7. Relative percent difference ${ }^{1}$ in trace-element concentrations in split samples analyzed at the U.S. Geological Survey National Water Quality Laboratory and the Rutgers University Chemistry Department laboratory, and a quality-assurance/quality-control reference standard analyzed at the U.S. Geological Survey National Water Quality Laboratory, New Jersey, 1993

[NA, not analyzed; *, one or both trace-element concentrations below detection limit]

\begin{tabular}{|c|c|c|c|c|c|c|c|}
\hline $\begin{array}{c}\text { Type of } \\
\text { sample, and } \\
\text { well number } \\
\text { for split } \\
\text { samples }\end{array}$ & Arsenic & Barium & Beryllium & Cadmium & Chromium & Cobalt & Copper \\
\hline \multicolumn{8}{|l|}{ Split samples: } \\
\hline 07- 497 & NA & 4.6 & NA & $*$ & $*$ & NA & 37.2 \\
\hline $07-603$ & NA & 8.7 & NA & * & $*$ & NA & 2 \\
\hline 07- 691 & NA & 11.8 & NA & * & * & NA & 16 \\
\hline $11-\quad 13$ & NA & 9.0 & NA & * & * & NA & 5 \\
\hline $11-\quad 20$ & NA & 11.6 & NA & $*$ & $*$ & NA & 9.1 \\
\hline $11-254$ & NA & 6.3 & NA & $*$ & $*$ & NA & 12.9 \\
\hline 11- 274 & NA & 11.8 & NA & $*$ & * & NA & 6.6 \\
\hline $11-281$ & NA & 18.3 & NA & $*$ & $*$ & NA & 5.1 \\
\hline $15-1065$ & NA & 9.5 & $\mathrm{NA}$ & * & * & NA & .4 \\
\hline 29- 586 & NA & 13.3 & NA & $*$ & * & NA & 4.8 \\
\hline Standard $^{3}$ & 4.9 & 12.8 & 0 & 28.6 & 0 & 4.1 & 0 \\
\hline
\end{tabular}

${ }^{1}$ Relative percent difference $=(|S-D|) \div((S+D) \div 2) \times 100$ where $S$ equals trace-element concentration in sample and $D$ equals traceelement concentration in split sample.

${ }^{2}$ Trace-element concentrations in samples and split samples used to calculate relative percent difference are provided in table 4.

${ }^{3}$ Commercially prepared reference standard analysis results are provided in table 6 . 
Table 7. Relative percent difference ${ }^{1}$ in trace-element concentrations in split samples analyzed at the U.S. Geological Survey National Water Quality Laboratory and the Rutgers University Chemistry Department laboratory, and a quality-assurance/quality-control reference standard analyzed at the U.S. Geological Survey National Water Quality Laboratory, New Jersey, 1993 -Continued

\begin{tabular}{|c|c|c|c|c|c|c|c|c|}
\hline $\begin{array}{c}\text { Type of } \\
\text { sample, and } \\
\text { well nnmber } \\
\text { for spllt } \\
\text { samples }^{2}\end{array}$ & Lead & Manganese & Thallum & Molybdenum & Nickel & Sliver & ZInc & Alnminnm \\
\hline \multicolumn{9}{|l|}{ Split samples: } \\
\hline 07- 497 & $*$ & 1.8 & NA & NA & * & NA & 21.6 & 1.5 \\
\hline 07- 603 & $*$ & 5.5 & NA & NA & 47.6 & NA & .7 & 5.9 \\
\hline 07- 691 & * & 3.4 & NA & NA & 60.8 & NA & 9.9 & 2.8 \\
\hline $11-\quad 13$ & 3.1 & 3.2 & NA & NA & 2 & NA & 12.2 & 1.3 \\
\hline $11-\quad 20$ & 1.3 & 9.3 & NA & NA & 28.9 & NA & 3.8 & .7 \\
\hline 11- 254 & 8.5 & .5 & NA & NA & 62.1 & NA & 1.3 & 1.7 \\
\hline $11-274$ & 10.3 & .6 & NA & NA & 12.2 & NA & 4.4 & 7.3 \\
\hline $11-281$ & 45.4 & 2.9 & NA & NA & 25.1 & NA & 10.5 & 12.2 \\
\hline $15-1065$ & 8.3 & 6.5 & NA & NA & I3.1 & NA & 32.5 & .6 \\
\hline 29- 586 & 8.2 & 3.3 & NA & $\mathrm{NA}$ & 53.3 & NA & 13.2 & .2 \\
\hline Standard & 9 & 9 & 18.2 & 0 & 6.9 & * & 9 & 4.3 \\
\hline
\end{tabular}



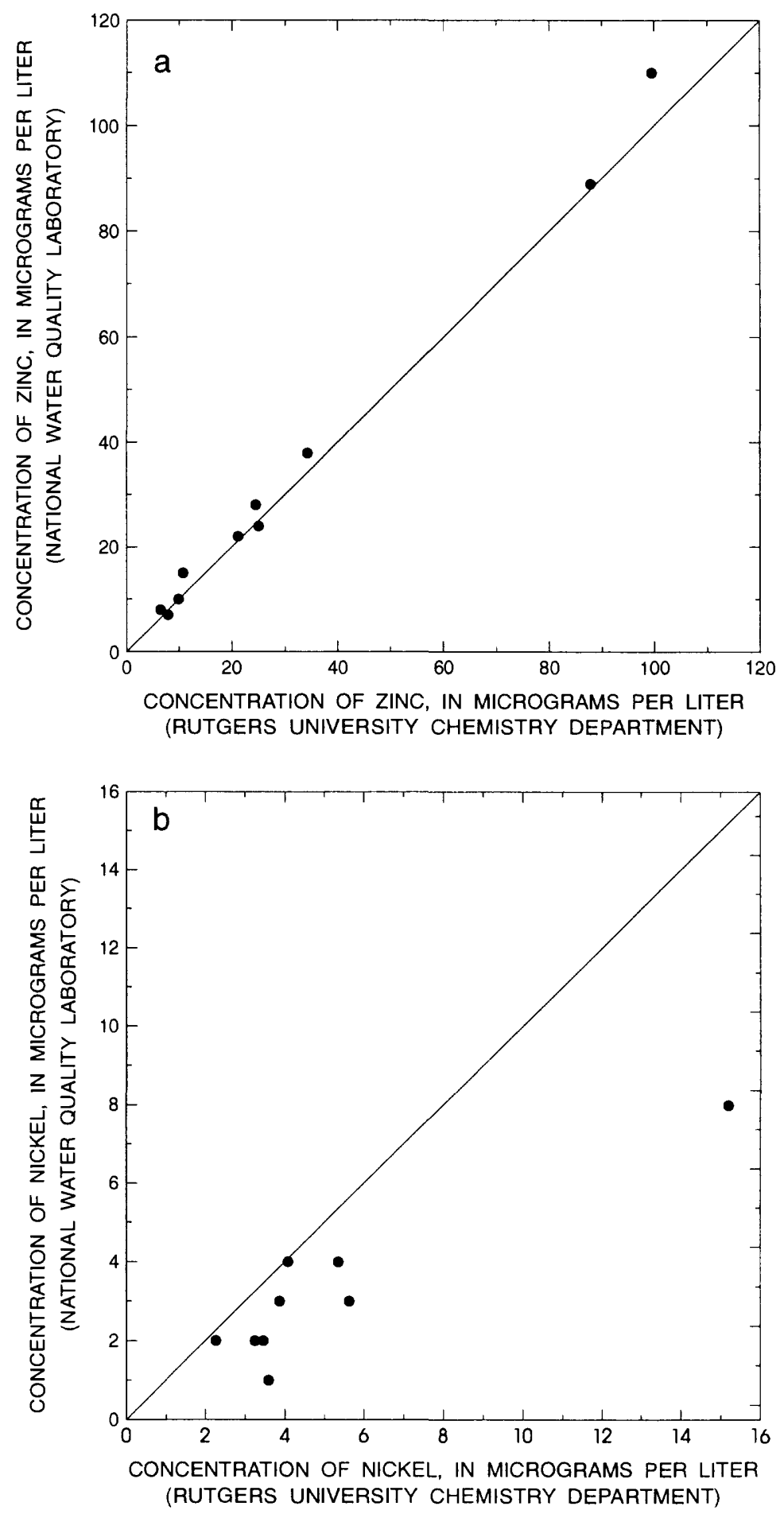

Figure 2. Concentrations of (a) zinc and (b) nickel in quality-assurance/quality-control split samples analyzed at the U.S. Geological Survey National Water Quality Laboratory and the Rutgers University Chemistry Department laboratory, New Jersey, 1993. 
A wilcoxon signed rank test (Helsel and Hirsch, 1992) was used to test whether there were significant differences between the ICP-MS concentration values of trace elements in the water-quality samples analyzed at the NWQL and those in the samples analyzed at the Rutgers laboratory. Differences were considered significant when the $\mathrm{p}-$ value was less than or equal to 0.05 . Results of the test indicated a significant difference between $\mathrm{Cr}$, $\mathrm{Ni}$ and $\mathrm{Zn}$ concentrations (p-values of 0.002 for $\mathrm{Cr}$ and $\mathrm{Ni}, 0.04$ for $\mathrm{Zn}$ ) from the two laboratories. The differences for $\mathrm{Zn}$ and $\mathrm{Ni}$ are illustrated in figure 2. No significant difference was determined for $\mathrm{Ba}, \mathrm{Cu}, \mathrm{Mn}$, and $\mathrm{Al}$.

The quality-assurance data from the NWQL and the Rutgers laboratory showed good agreement, which indicates that the measured trace-element concentrations were representative, precise, and accurate. The results of analysis of the equipment blanks show that the ultra-clean sampling protocol eliminates microgram-per-liter-level traceelement contamination of the samples. However, even though the quality-assurance data from the NWQL agreed well between the split sample and the reference standard sample of known concentrations, statistical conclusions on precision and accuracy cannot be made because of the small number of samples (one split sample, one standard sample).

\section{SUMMARY}

Water samples collected during 1993 from 22 public supply wells screened in the Kirkwood-Cohansey aquifer system and located in agricultural and non-agricultural areas were analyzed for arsenic $(\mathrm{As})$, barium $(\mathrm{Ba})$, beryllium $(\mathrm{Be})$, cadmium $(\mathrm{Cd})$, chromium $(\mathrm{Cr})$, cobalt $(\mathrm{Co})$, copper $(\mathrm{Cu})$, lead $(\mathrm{Pb})$, manganese $(\mathrm{Mn})$, thallium $(\mathrm{Tl})$, molybdenum (Mo), nickel (Ni), silver ( $\mathrm{Ag})$, zinc ( $\mathrm{Zn})$, antimony $(\mathrm{Sb})$, aluminum ( $\mathrm{Al})$, mercury $(\mathrm{Hg})$, and uranium (U). Low-level trace-element sampling protocols were used to collect water samples, and inductively coupled plasma-mass spectrometry (ICP-MS) analyses capable of producing accurate and precise results at the microgram-per-liter level (reporting limit $1 \mu \mathrm{g} / \mathrm{L}$ for all elements except $\mathrm{Hg}$ which had a $0.1 \mu \mathrm{g} / \mathrm{L}$ reporting limit ) were used to analyze those samples. Although the ICP-MS analytical technology can produce results at the required level of precision and accuracy, sampling protocols must ensure against microgram-per-liter-level trace-element contamination; hence the need to design and test an "ultra-clean" sampling protocol during the study. Trace-element concentrations determined during 1986-90 by inductively coupled plasma-atomic emission spectroscopy (ICP-AES) for water samples from 21 of the same wells are included in this report for comparison with 1993 water-quality data.

In general, turbidity of the samples was equal to or less than 1 NTU, except for that of the samples from two infrequently used wells indicating that trace elements carried on particulates did not compromise sample integrity. Results of the trace-element analysis indicate that 5 of the measured 18 trace elements analyzed for-- $\mathrm{Co}, \mathrm{Cu}, \mathrm{Pb}, \mathrm{Hg}$, and $\mathrm{Ni}$-- 
were detectable in concentrations ranging from $<0.1$ to $29 \mu \mathrm{g} / \mathrm{L}$ in most of the samples from the 22 wells, whereas 4 elements-- $\mathrm{Al}, \mathrm{Ba}, \mathrm{Mn}$, and $\mathrm{Zn}$--were detected in a higher range of concentrations in most samples (from 30 to $710 \mu \mathrm{g} / \mathrm{L}$ for $\mathrm{Al}$, and from 4.0 to 180 $\mu \mathrm{g} / \mathrm{L}$ for $\mathrm{Ba}, \mathrm{Mn}$, and $\mathrm{Zn}$ ). Concentrations of $\mathrm{As}, \mathrm{Be}, \mathrm{Cd}, \mathrm{Cr}, \mathrm{Sb}, \mathrm{Mo}, \mathrm{Tl}, \mathrm{Ag}$, and $\mathrm{U}$ in samples from all wells were less than the detection limit $(1 \mu \mathrm{g} / \mathrm{L})$. The concentration of $\mathrm{Pb}(16 \mu \mathrm{g} / \mathrm{L})$ in one water sample exceeded the U.S. Environmental Protection Agency's (USEPA) action level $(15 \mu \mathrm{g} / \mathrm{L})$, and the concentration of $\mathrm{Hg}$ in the sample from well 29$428(1.1 \mu \mathrm{g} / \mathrm{L})$ approached the USEPA maximum contamination limit MCL of $2 \mu \mathrm{g} / \mathrm{L}$.

Sampling-equipment blanks were demonstrated to be free of low-level traceelement contamination. Concentrations of all trace elements analyzed for by using ICPMS were less than the reporting limit of $1 \mu \mathrm{g} / \mathrm{L}$ for the U.S. Geological Survey National Water Quality Laboratory (NWQL) and $0.2 \mu \mathrm{g} / \mathrm{L}$ for the Rutgers University Chemistry Department laboratory (Rutgers laboratory). One blank sample analyzed at the NWQL contained $\mathrm{Zn}$ in a concentration of $1 \mu \mathrm{g} / \mathrm{L}$, and the blank sample analyzed at the Rutgers laboratory contained $\mathrm{Zn}$ in a concentration of $0.26 \mu \mathrm{g} / \mathrm{L}(0.2 \mu \mathrm{g} / \mathrm{L}$ detection limit at the Rutgers laboratory), indicating random $\mathrm{Zn}$ contamination at low levels cannot be completely eliminated.

Analysis of the blindly submitted, commercially prepared National Institute of Standards reference standard solution by ICP-MS at the NWQL produced results that were in agreement with the known concentrations of the trace elements. The relative percent difference between the analytically determined concentrations and the known values was 10 percent or less, except for three elements--Ba, $\mathrm{Cd}$ and $\mathrm{Tl}$. The analytically determined concentrations of $\mathrm{Cd}$ and $\mathrm{Tl}$ were 0.5 to $1.0 \mu \mathrm{g} / \mathrm{L}$ higher than the known values, whereas that of $\mathrm{Ba}$ was $0.5 \mu \mathrm{g} / \mathrm{L}$ lower.

The relative difference between the trace-element concentrations in a sample analyzed by the NWQL and those in the split sample was 5 percent or less, with the exception of aluminum, for which the difference was 10 percent; this large difference is attributed to inherent difficulties in analyzing for this trace element by ICP-MS.

Concentrations of trace elements determined in 10 split samples analyzed at the NWQL and at the Rutgers laboratory showed good agreement (within 10 percent), except for Ni. Results of analyses conducted at the Rutgers laboratory indicated an apparent low bias for concentrations of $\mathrm{Ba}, \mathrm{Mn}$, and $\mathrm{Zn}$ in most samples compared to those determined at the NWQL. Concentrations of Cr reported by the NWQL were all less than the reporting limit; however, $\mathrm{Cr}$ was not detected at the Rutgers laboratory. Nickel was the only trace element with a high bias in concentrations measured at the Rutgers laboratory relative to those measured at the NWQL; every concentration was higher than the corresponding concentration from the NWQL. These results indicate that the sampling 
procedure is effective, that both laboratories are free of low-level trace-element contamination (except for $\mathrm{Zn}$ ), and that analyses with ICP-MS can be accurate, precise, and reproducible between laboratories, provided the integrity of the sample is not compromised during sampling. The trace-element concentrations determined in the samples from the public supply wells during this study can be used, therefore, as a baseline to determine, for example, whether the application of agricultural chemicals over time results in increasing concentrations and a redistribution of trace elements in the aquifer system. 


\section{REFERENCES CITED}

Backhus, D.A., Ryan, J.N., Groher, D.M., MacFarlane, J.K., and Gschwend, P.M., 1993, Sampling colloids and colloid-associated contaminants in ground water: Ground Water, v.31, no. 3, p. 466-479.

Barringer, T.H., Szabo, Zoltan, and Kozinski, Jane, 1991, Relations between nitrate and radium rank concentrations in ground water in the Kirkwood-Cohansey aquifer system, New Jersey, in Statistics and the environment: American Statistical Association winter conference, New Orleans, La., p. 48.

Chow, T.J., and Earl, J.L., 1970, Lead aerosols in the atmosphere--increasing concentrations: Science, v. 169, p. 577-580.

Date, A.R., and Gray, A.L., eds., 1989, Applications of inductively coupled plasma mass spectrometry: Glasgow, U.K., Blackie and Son Limited, 273 p.

Faires, L.M., 1993, Methods of analysis by the U.S. Geological Survey National Water Quality Laboratory-Determination of metals in water by inductively coupled plasmamass spectrometry: U.S. Geological Survey Open-File Report 92-634, 28 p.

Fishman, M.J., and Friedman, L.C., 1985, Methods for determination of inorganic substances in water and fluvial sediments: U.S. Geological Survey Techniques of Water-Resources Investigations, book 5, chap. A1, 709 p.

1989, Methods for determination of inorganic substances in water and fluvial sediments: U.S. Geological Survey Techniques of Water-Resources Investigations, book 5 , chap. A1, $545 \mathrm{p}$.

Helsel, D.R. and Hirsch, R.M., 1992, Statistical Methods in Water Resources: New York, Elsevier, 529 p.

Horowitz, A.J., Demas, C.R., Fitzgerald, K.K., Miller, T.L., and Rickert, D.A., 1994, U.S. Geological Survey protocol for the collection and processing of surface-water samples for the subsequent determination of inorganic constituents in filtered water: U.S. Geological Survey Open-File Report 94-539, 57 p.

Johnson, A.H., Siccama, T.G., and Friedland, A.J., 1982, Spatial and temporal patterns of lead accumulation in the forest floor in the northeastern United States: Journal of Environmental Quality, v. 11, p. 577-580. 


\section{REFERENCES CITED--Continued}

Kozinski, Jane, Szabo, Zoltan, Zapecza, O.S., and Barringer, T.H., 1995, Natural radioactivity in, and inorganic chemistry of, ground water in the Kirkwood-Cohansey aquifer system, southern New Jersey, 1983-89: U.S. Geological Survey Water Resources Investigations Report 92-4144, 130 p.

Lacombe, P.J., and Rosman, Robert, 1995, Hydrology of the unconfined aquifer system, upper Maurice River Basin and adjacent areas in Gloucester County, New Jersey, 1986-87: U.S. Geological Survey Water-Resources Investigations Report 92-4128, 5 sheets.

Martin, Mary, in press, Ground-water flow in the New Jersey Coastal Plain: U.S. Geological Survey Professional Paper 1404-H, 182 p.

Swain, E., Engstrom, D., Brigham, M., Henning, T., and Brezonik, D., 1992, Increasing rates of atmospheric mercury deposition in midcontinental North America: Science, v. 257 , p. $784-787$.

U.S. Environmental Protection Agency, 1979, Methods for chemical analysis of water and wastes: Cincinnati, Ohio, p. 245.1-1.

1990, Primary drinking-water regulations, maximum contaminant levels (Appendix B to part 136, National primary drinking-water regulations): U.S. Code of Federal Regulations, Title 40, parts 100-149, revised as of July 1, 1990, p. 537-539.

1991, Final rule, Primary drinking-water regulations--Synthetic organic chemicals and inorganic chemicals (sections 141.11, 141.12, 141.32, 141.50, 141.61, and 141.62, of part 141 and 143.3 of part 143): U.S. Federal Register, v. 56, no. 20, January 30,1991 p. 3526-3597.

Wood, W.W., 1976, Guidelines for collection and field analysis of ground-water samples for selected unstable constituents in water and fluvial sediments: U.S. Geological Survey Techniques of Water-Resources Investigations, book 1, chap. D2, p. 24.

Zapecza, O.S., 1989, Hydrogeologic framework of the New Jersey Coastal Plain: U.S. Geological Survey Professional Paper 1404-B, 49 p., 24 pl. 


\section{GLOSSARY}

Aquifer: A geologic formation, group of formations, or part of a formation that contains sufficient saturated permeable material to yield significant quantities of water to wells and springs.

Dissolved: Chemical constituents in a water sample that pass through a 0.45 -micrometer membrane filter. This is a convenient operational definition used by Federal agencies that collect water data. Determinations of "dissolved" constituents are made on subsamples of the filtrate.

Element: Any substance identified by a specific number of protons in its nucleus (known as the atomic number) that cannot be separated into smaller component substances except by nuclear disintegration (radioactivity).

Equipment blank: A blank solution that is subjected to all aspects of sample collection, field processing, preservation, transportation to the laboratory, and laboratory handling as an environmental sample, but is generated in the relatively controlled environment of a laboratory.

Field-measured characteristics: A phrase used to identify characteristics determined in the field when the water sample is collected. Water temperature, specific conductance, $\mathrm{pH}$, and dissolved-oxygen concentration are considered field-measured characteristics in this study.

Isotope: Any of two or more forms of an element that have different atomic weights due to different numbers of neutrons found in the nucleus. The chemical properties of isotopes are identical.

Maximum contamination level (MCL): Maximum permissible level of a contaminant in water which is delivered to the free-flowing outlet of the ultimate user of a public water system.

Maximum contamination level goal: A non-enforceable concentration of a drinking water contaminant that is protective of adverse human health effects and allows an adequate margin of safety. 


\section{GLOSSARY--Continued}

Micrograms per liter $(\mu \mathrm{g} / \mathrm{L})$ : A unit expressing the concentration of chemical constituents in solution as the mass (microgram $=1 \times 10^{-6}$ gram) of solute per unit volume (liter) of water. One thousand micrograms per liter is equivalent to one milligram per liter. One microgram per liter is approximately equal to 1 part per billion (ppb) in aqueous solutions of low dissolved-solids concentration.

Milligrams per liter $(\mathrm{mg} / \mathrm{L})$ : A unit expressing the concentration of chemical constituents in solution as the mass (milligram $=1 \times 10^{-3}$ gram) of solute per unit volume (liter) of water. For water containing less than $7,000 \mathrm{mg} / \mathrm{L}$ dissolved solids, the numerical value for milligrams per liter of a constituent is the same as for the concentration in parts per million (ppm).

Minimum reporting limit: For a given type of sample and analytical procedure, the concentration value below which the presence of the constituent being analyzed can be neither verified nor denied. Minimum detection limits can be identified in the tables of this report by a "less than" $(<)$ symbol preceding a numerical value. The reported minimum detection limit can vary from analysis to analysis for any single constituent.

Nephelometric turbidity unit (NTU): A unit expressing the measurement of the intensity of light scattered by suspended particles in the water column.

Picocuries per liter ( $\mathrm{pCi} / \mathrm{L})$ : A unit expressing the concentration of radioactive constituents in solution as the radioactivity (picocuries) of the solute per unit volume (liter) of water. One picocurie is equal to $1 \times 10^{-12}$ Curies, where one Curie is the amount of radiation emitted by one gram of radium. One picocurie represents 2.2 radioactive decays per second.

Radioactivity: The disintegration of the nucleus of an atom of element giving off energy in the forms of alpha (a nucleus of a helium atom) and beta (an electron) particles and in gamma rays. A different element is produced by the radioactive decay.

Radionuclide: A specific isotope of an element that is radioactive (will undergo a form of radioactive decay).

Replicate samples: A group of samples, collected in a manner such that the samples are thought to be essentially identical in composition. There are many types of replicate samples, each of which may yield slightly different results in a dynamic hydrologic setting. 


\section{GLOSSARY--Continued}

Secondary maximum contaminant level (SMCL): Contaminants that affect the aesthetic quality of drinking water. At high concentrations, health implications as well as aesthetic degradation may also exist. SMCLs are not Federally enforceable but are intended as guidelines for State agencies.

Split sample: A type of replicate sample in which a sample is split into subsamples that are contemporaneous in time and space. 
Table 3. Physical properties of, and concentrations of, trace elements, nutrients, calcium, magnesium, and selected radioactive elements and radionuclides in, water samples from public supply wells in the Kirkwood-Cohansey aquifer system, New Jersey, 1986-90

$\left[{ }^{\circ} \mathrm{C}\right.$, degrees Celsius; $\mu \mathrm{S} / \mathrm{cm}$, microsiemens per centimeter at $25^{\circ} \mathrm{C} ; \mathrm{mg} / \mathrm{L}$, milligrams per liter; $\mu \mathrm{g} / \mathrm{L}$, micrograms per liter; pCi/L, picocuries per liter; <, less than; --, data not available; Ra, radium; trace-element analyses were performed by using inductively coupled plasma-atomic emission spectroscopy or direct current plasma-atomic emission spectroscopy]

\begin{tabular}{|c|c|c|c|c|c|c|c|c|}
\hline $\begin{array}{c}\text { Well } \\
\text { number }\end{array}$ & Date & $\begin{array}{c}\text { Temperature } \\
\text { water } \\
\left({ }^{\circ} \mathrm{C}\right)\end{array}$ & $\begin{array}{c}\text { Specific } \\
\text { conductance } \\
(\mu \mathrm{S} / \mathrm{cm})\end{array}$ & $\begin{array}{c}\text { Oxygen, } \\
\text { dissolved } \\
(\mathrm{mg} / \mathrm{L})\end{array}$ & $\begin{array}{c}\text { pH } \\
\text { water, } \\
\text { field } \\
\text { (standard } \\
\text { units) }\end{array}$ & $\begin{array}{c}\text { Arsenic, } \\
\text { dissolved } \\
(\mu \mathrm{g} / \mathrm{L} \\
\text { as } \mathbf{A s})\end{array}$ & $\begin{array}{c}\text { Barium, } \\
\text { dissolved } \\
(\mu \mathrm{g} / \mathrm{L} \\
\text { as Ba) }\end{array}$ & $\begin{array}{c}\text { Beryllium, } \\
\text { dissolved } \\
(\mu \mathrm{g} / \mathrm{L} \\
\text { as Be) }\end{array}$ \\
\hline $01-230$ & $12-06-88$ & I4.0 & 49 & 4.4 & 5.2 & $<I$ & 36 & $<0.5$ \\
\hline 07. 490 & $12-16-88$ & 11.5 & 92 & 5.1 & 5.3 & $<1$ & 56 & $<.5$ \\
\hline 07- 497 & $12-16-88$ & 12.5 & 54 & 5.0 & 5.7 & $<1$ & 29 & $<.5$ \\
\hline 07.603 & $12-02-88$ & 13.0 & 127 & 7.5 & 5.0 & $<1$ & 130 & $<.5$ \\
\hline 07- 691 & $07-18-90$ & I3.5 & 66 & 4.1 & 5.1 & -. & 55 & $<.5$ \\
\hline \multirow[t]{2}{*}{$11-3$} & $12-07-88$ & 12.5 & 81 & 9.7 & 4.5 & $<1$ & 77 & $<.5$ \\
\hline & & 12.5 & 81 & 9.7 & 4.5 & $<1$ & 77 & $<.5$ \\
\hline 11- 13 & $12-06-88$ & $\mathrm{I} 2.5$ & 121 & 6.2 & 4.6 & $<1$ & 63 & $<.5$ \\
\hline 11- 20 & $12-06-88$ & I4.0 & 93 & 5.2 & 4.8 & $<1$ & 58 & $<.5$ \\
\hline 11. 254 & I 1-30-88 & 12.0 & 97 & 1.4 & 4.3 & $<1$ & 86 & $<.5$ \\
\hline 11. 255 & $11-30-88$ & 12.5 & 73 & 4.I & 4.4 & $<1$ & 51 & $<.5$ \\
\hline 11- 274 & $12-08-88$ & 12.5 & 125 & 6.1 & 4.7 & $<1$ & 180 & $<.5$ \\
\hline $111-278$ & $12-09-88$ & 11.5 & 38 & 6.9 & 5.1 & $<1$ & 27 & $<.5$ \\
\hline 11- 281 & $12-07-88$ & 12.5 & 142 & 5.9 & 4.8 & $<1$ & 100 & $<.5$ \\
\hline $11-361$ & $12-07-88$ & 13.5 & 120 & 5.1 & 4.6 & $<1$ & 55 & $<.5$ \\
\hline $15-375$ & $11-20-86$ & 13.0 & 100 & 2.8 & 4.5 & -. & 82 & $<.5$ \\
\hline $15-1048$ & $08-15-90$ & 12.5 & 30 & 6.7 & 5.0 & -- & 11 & $<.5$ \\
\hline $15-1065$ & $07-17-90$ & 13.5 & 92 & 8.7 & 4.9 & -- & 180 & $<.5$ \\
\hline 29. 88 & $07-12-90$ & 13.0 & 126 & 6.2 & 4.7 & $<1$ & 57 & $<.5$ \\
\hline 29- 428 & $07-12-90$ & 13.5 & 129 & 3.1 & 5.1 & $<1$ & 25 & $<.5$ \\
\hline 29- 488 & $07-13-90$ & 13.0 & 34 & .1 & 4.7 & $<1$ & 20 & .6 \\
\hline 29. 586 & $07-11-90$ & 14.0 & 77 & 5.5 & 4.7 & $<1$ & 30 & $<.5$ \\
\hline 29- 735 & $07-11-90$ & 13.0 & 57 & 3.3 & 4.5 & $<1$ & 28 & .6 \\
\hline
\end{tabular}

${ }^{1}$ Well sealed in 1993 
Table 3. Physical properties of, and concentrations of, trace elements, nutrients, calcium, magnesium, and selected radioactive elements and radionuclides in, water samples from public supply wells in the Kirkwood-Cohansey aquifer system, New Jersey 1986-90-Continued

\begin{tabular}{|c|c|c|c|c|c|c|c|c|c|c|}
\hline $\begin{array}{c}\text { Well } \\
\text { number }\end{array}$ & Date & $\begin{array}{c}\text { Cadmíum, } \\
\text { dissolved } \\
(\mu \mathrm{g} / \mathrm{L} \\
\text { as Cd) }\end{array}$ & $\begin{array}{c}\text { Chromium, } \\
\text { dissolved } \\
(\mu \mathrm{g} / \mathrm{L} \\
\text { as } \mathrm{Cr})\end{array}$ & $\begin{array}{c}\text { Cobalt, } \\
\text { dissolved } \\
(\mu \mathrm{g} / \mathrm{L} \\
\text { as Co })\end{array}$ & $\begin{array}{c}\text { Copper, } \\
\text { dissolved } \\
(\mu \mathrm{g} / \mathrm{L} \\
\text { as Cu })\end{array}$ & $\begin{array}{c}\text { Lead, } \\
\text { dissolved } \\
(\mu \mathrm{g} / \mathbf{l} \\
\text { as } \mathbf{P b})\end{array}$ & $\begin{array}{c}\text { Manga- } \\
\text { nese, } \\
\text { dissolved } \\
(\mu \mathrm{g} / \mathbf{L} \\
\text { as } \mathbf{M n )}\end{array}$ & $\begin{array}{c}\text { Molyb- } \\
\text { denum, } \\
\text { dissolved } \\
(\mu \mathrm{g} / \mathrm{L} \\
\text { as Mo) }\end{array}$ & $\begin{array}{c}\text { Nickel, } \\
\text { dissolved } \\
(\mu \mathrm{g} / \mathrm{L} \\
\text { as Ni) }\end{array}$ & $\begin{array}{c}\text { Silver, } \\
\text { dissolved } \\
(\mu \mathrm{g} / \mathrm{L} \\
\text { as } \mathbf{A g})\end{array}$ \\
\hline $01-230$ & $12-06-88$ & $<1$ & $<5$ & $<3$ & 30 & $<10$ & 44 & $<10$ & $<10$ & $<1.0$ \\
\hline 07- 490 & $12-16-88$ & $<1$ & $<5$ & $<3$ & $<10$ & $<10$ & 11 & $<10$ & $<10$ & $<1.0$ \\
\hline 07- 497 & $12-16-88$ & $<1$ & $<5$ & $<3$ & $<10$ & $<10$ & 16 & $<10$ & $<10$ & $<1.0$ \\
\hline $07-603$ & $12-02-88$ & $<1$ & $<5$ & $<3$ & $<10$ & $<10$ & 31 & $<10$ & $<10$ & $<1.0$ \\
\hline 07- 691 & $07-18-90$ & $<1$ & $<5$ & $<3$ & $<10$ & $<10$ & 76 & $<10$ & $<10$ & $<\mathrm{I} .0$ \\
\hline \multirow[t]{2}{*}{$11-3$} & $12-07-88$ & $<1$ & $<5$ & $<3$ & 40 & $<10$ & 17 & $<10$ & $<10$ & $<1.0$ \\
\hline & & $<1$ & $<5$ & $<3$ & 40 & 10 & 17 & $<10$ & $<10$ & $<1.0$ \\
\hline 11. 13 & $12-06-88$ & $<1$ & $<5$ & $<3$ & 10 & $<10$ & 26 & $<10$ & $<10$ & $<1.0$ \\
\hline $11-20$ & $12-06-88$ & $<1$ & $<5$ & $<3$ & 40 & $<10$ & 11 & $<10$ & $<10$ & 1.0 \\
\hline 11.254 & $11-30-88$ & $<1$ & $<5$ & 6 & 40 & $<10$ & 60 & $<10$ & $<10$ & $<1.0$ \\
\hline $11-255$ & $1 \mathrm{I}-30-88$ & $<1$ & $<5$ & $<3$ & 20 & $<10$ & 14 & $<10$ & $<10$ & $<1.0$ \\
\hline 11- 274 & $12-08-88$ & $<1$ & $<5$ & $<3$ & 40 & $<10$ & 27 & $<10$ & $<10$ & $<1.0$ \\
\hline $11-278$ & $12-09-88$ & $<1$ & $<5$ & $<3$ & $<10$ & $<10$ & 5 & $<10$ & $<10$ & $<1.0$ \\
\hline 11- 281 & $12-07-88$ & $<1$ & $<5$ & $<3$ & 40 & 10 & 19 & $<10$ & $<10$ & $<1.0$ \\
\hline 11- 361 & $12-07-88$ & $<1$ & $<5$ & $<3$ & 20 & $<10$ & 20 & $<10$ & $<10$ & $<1.0$ \\
\hline 15. 375 & $11-20-86$ & 1 & -- & $<3$ & 20 & $<10$ & 21 & $<10$ & -- & -- \\
\hline $15-1048$ & $08-15-90$ & $<1$ & $<5$ & $<3$ & $<10$ & $<10$ & 8 & $<10$ & $<10$ & $<1.0$ \\
\hline $15-1065$ & $07-17-90$ & $<1$ & $<5$ & $<3$ & $<10$ & $<10$ & 28 & $<10$ & $<10$ & $<1.0$ \\
\hline 29- 88 & $07-12-90$ & $<1$ & $<5$ & $<3$ & $<10$ & $<10$ & 31 & $<10$ & $<10$ & $<1.0$ \\
\hline 29- 428 & $07-12-90$ & $<1$ & $<5$ & $<3$ & 10 & $<10$ & 48 & $<10$ & $<10$ & $<1.0$ \\
\hline 29- 488 & $07-13-90$ & $<1$ & $<5$ & $<3$ & $<10$ & $<10$ & 8 & $<10$ & $<10$ & $<\mathrm{I} .0$ \\
\hline 29. 586 & $07-11-90$ & $<1$ & $<5$ & $<3$ & 80 & $<10$ & 18 & $<10$ & $<10$ & $<1.0$ \\
\hline 29. 735 & $07-11-90$ & $<1$ & $<5$ & $<3$ & 20 & $<10$ & 11 & $<10$ & $<10$ & $<1.0$ \\
\hline
\end{tabular}


Table 3. Physical properties of, and concentrations of, trace elements, nutrients, calcium, magnesium, and selected radioactive elements and radionuclides in, water samples from public supply wells in the Kirkwood-Cohansey aquifer system, New Jersey 1986-90--Continued

\begin{tabular}{|c|c|c|c|c|c|c|c|c|c|c|}
\hline $\begin{array}{c}\text { Well } \\
\text { nnmber }\end{array}$ & Date & $\begin{array}{l}\text { Mercury, } \\
\text { dis- } \\
\text { solved } \\
(\mu \mathrm{g} / \mathrm{L} \text { as } \\
\text { Hg) }\end{array}$ & $\begin{array}{c}\text { Zinc, } \\
\text { dissolved } \\
(\mu \mathrm{g} / \mathrm{L} \\
\text { as } \mathrm{Zn})\end{array}$ & $\begin{array}{c}\text { Aluminum, } \\
\text { dissolved } \\
(\mu \mathrm{g} / \mathrm{L} \\
\text { as } \mathrm{Al})\end{array}$ & $\begin{array}{c}\text { Uranium, } \\
\text { natural, } \\
\text { dissolved } \\
(\mu \mathrm{g} / \mathrm{L} \\
\text { as } \mathrm{U})\end{array}$ & $\begin{array}{c}\text { Uranlum } \\
\text { natural, } \\
2 \text { sigma } \\
\text { water, } \\
\text { dissolved } \\
(\mu \mathrm{g} / \mathrm{L})\end{array}$ & $\begin{array}{l}\text { Radium- } \\
226, \\
\text { dissolved } \\
\text { radon } \\
\text { method } \\
(\mathrm{pCl} / \mathrm{L})\end{array}$ & $\begin{array}{c}\text { Ra-226 } \\
2 \text { sigma } \\
\text { water, } \\
\text { dissolved } \\
\text { (pCl/L) }\end{array}$ & $\begin{array}{l}\text { Radium- } \\
228, \\
\text { dissolved } \\
\text { (pCy/L } \\
\text { as } \\
\text { Ra-228) }\end{array}$ & $\begin{array}{c}\text { Ra-228 } \\
2 \text { sigma } \\
\text { water, } \\
\text { dissolved } \\
(\mathrm{pCl} / \mathrm{L})\end{array}$ \\
\hline $01-230$ & $12-06-88$ & $<0.1$ & 81 & 40 & $<0.01$ & -- & 0.43 & -. & 1.2 &.- \\
\hline 07. 490 & $12-16-88$ & $<.1$ & 10 & 40 & .01 & -- & 1.7 & -- & 3.0 & - \\
\hline 07. 497 & $12-16-88$ & $<.1$ & 4 & 40 & .03 & -- & .87 & -- & $<1.0$ & -- \\
\hline 07. 603 & $12-02-88$ & .2 & 10 & 100 & .19 & -- & 4.1 & -. & 3.2 & -. \\
\hline 07- 691 & $07-18-90$ & -- & 34 & 30 & .01 & $<1.0$ & 2.5 & .340 & 1.7 & .7 \\
\hline & $12-07-88$ & -- & 120 & 150 & .02 & .. & 1.9 & -- & 3.6 & -- \\
\hline & & -- & 120 & 150 & .03 & -- & 2.1 & -- & 3.4 & -- \\
\hline 11. 13 & $12-06-88$ & -- & 6 & 310 & .14 & -- & 4.2 & -- & 3.3 & -- \\
\hline 11. 20 & $12-06-88$ & -- & 31 & 280 & .04 & -- & 1.9 & -- & 2.7 & -- \\
\hline 11- 254 & $11-30-88$ & -- & 72 & 530 & .06 & -- & 2.1 & -- & 3.3 & -- \\
\hline 11- 255 & $11-30-88$ & -- & 21 & 350 & .02 & -. & 1.5 & -- & 1.8 & .. \\
\hline 11. 274 & $12-08-88$ & -. & $<3$ & 130 & .09 & -- & 4.0 & -- & 3.0 & -- \\
\hline 11- 278 & $12-09-88$ & -- & 24 & 90 & .02 & -- & .90 & -- & 1.3 & -- \\
\hline 11. 281 & $12-07-88$ & -- & 26 & 60 & .01 & -- & 2.5 & -. & 2.1 & -- \\
\hline 11. 361 & $12-07-88$ & -. & 15 & 700 & .07 & -- & 1.8 &.. & 2.3 & - \\
\hline 15- 375 & $11-20-86$ & -- & 25 & 220 & -- & -- & -- & -- & -- & -- \\
\hline $15-1048$ & $08-15-90$ & -- & 11 & 200 & .02 & -. & .31 & -- & $<1.0$ & -- \\
\hline $15-1065$ & $07-17-90$ &.- & 26 & 110 & .02 & $<1.0$ & 2.2 & .310 & 2.2 & .9 \\
\hline $29-88$ & $07-12-90$ & -. & 30 & 170 & .04 & $<1.0$ & 2.4 & .330 & 1.7 & -- \\
\hline 29- 428 & $07-12-90$ & -. & 24 & 190 & .04 & $<1.0$ & 1.2 & .160 & 2.1 & -- \\
\hline 29- 488 & $07-13-90$ & -- & 6 & 100 & $<.01$ & $<1.0$ & .18 & .030 & $<1.0$ & -. \\
\hline 29- 586 & $07-11-90$ & -- & 4 & 110 & .07 & $<1.0$ & 1.6 & .220 & 1.7 & -- \\
\hline 29- 735 & $07-11-90$ & -- & 11 & 400 & .05 & $<1.0$ & .92 & .130 & 1.9 & -- \\
\hline
\end{tabular}


Table 3. Physical properties of, and concentrations of, trace elements, nutrients, calcium, magnesium, and selected radioactive elements and radionuclides in, water samples from public supply wells in the Kirkwood-Cohansey aquifer system, New Jersey 1986-90--Continued

\begin{tabular}{|c|c|c|c|c|c|c|c|c|}
\hline $\begin{array}{c}\text { Well } \\
\text { number }\end{array}$ & Date & $\begin{array}{c}\text { Alkalinity, } \\
\text { lab } \\
(\mathrm{mg} / \mathrm{L} \\
\text { as } \\
\left.\mathrm{CaCO}_{3}\right)\end{array}$ & $\begin{array}{c}\text { Nitrogen, } \\
\text { ammonla } \\
\text { dissolved } \\
(\mathrm{mg} / \mathrm{L} \\
\text { as } \mathrm{N})\end{array}$ & $\begin{array}{l}\text { Nitrogen, } \\
\text { nitrite } \\
\text { dissolved } \\
(\mathrm{mg} / \mathrm{L} \\
\text { as } \mathrm{N}\end{array}$ & $\begin{array}{c}\text { Nitrogen, } \\
\text { ammonia } \\
\text { and } \\
\text { organic } \\
\text { dissolved } \\
(\mathrm{mg} / \mathrm{L} \\
\text { as } \mathrm{N})\end{array}$ & $\begin{array}{c}\text { Nitrogen, } \\
\mathrm{NO}_{2}+\mathrm{NO}_{3} \\
\text { dissolved } \\
(\mathrm{mg} / \mathrm{L} \\
\text { as } \mathrm{N})\end{array}$ & $\begin{array}{c}\text { Calcium, } \\
\text { dissolved } \\
\text { (mg/L } \\
\text { as Ca) }\end{array}$ & $\begin{array}{c}\text { Magnesium, } \\
\text { dissolved } \\
(\mathbf{m g} / \mathbf{L} \\
\text { as } \mathbf{M g})\end{array}$ \\
\hline 01.230 & $12-06-88$ & 4.0 & $<0.010$ & 0.010 & 0.20 & 1.10 & 1.3 & 0.78 \\
\hline 07. 490 & $12-16-88$ & 5.0 & $<.010$ & $<.010$ & .60 & 4.90 & 4.6 & 2.8 \\
\hline 07. 497 & $12-16-88$ & 8.0 & .040 & $<.010$ & .20 & .800 & 3.3 & 1.7 \\
\hline 07. 603 & $12-02-88$ & 2.0 & $<.010$ & $<.010$ & .50 & 5.60 & 7.2 & 4.8 \\
\hline (17- 691 & $07-18-90$ & 3.1 & .060 & $<.010$ & $<.20$ & .800 & 2.8 & .95 \\
\hline \multirow[t]{2}{*}{$11-3$} & $12-07-88$ & $<1.0$ & $<.010$ & $<.010$ & .20 & 3.50 & 2.3 & 2.2 \\
\hline & & $<1.0$ & $<.010$ & $<.010$ & .60 & 3.50 & 2.3 & 2.1 \\
\hline $11-\quad 13$ & $12-06-88$ & 1.0 & $<.010$ & $<.010$ & .60 & 6.20 & 4.6 & 4.3 \\
\hline $11-20$ & $12-06-88$ & 1.0 & .110 & $<.010$ & .30 & 3.20 & 3.4 & 2.5 \\
\hline 11- 254 & $11-30-88$ & $<1.0$ & $<.010$ & $<.010$ & .20 & 2.00 & 3.2 & 2.2 \\
\hline $11-2.55$ & $11-30-88$ & $<1.0$ & $<.010$ & $<.010$ & .20 & 3.10 & 2.5 & 1.5 \\
\hline $11-274$ & $12-08-88$ & 1.0 & $<.010$ & $<.010$ & 1.1 & 7.40 & 4.8 & 5.5 \\
\hline $11-278$ & $12-09-88$ & 2.0 & .010 & .010 & .20 & 1.40 & 1.6 & .83 \\
\hline 11. 281 & $12-07-88$ & 2.0 & $<.010$ & $<.010$ & 1.5 & 7.50 & 8.2 & 5.4 \\
\hline 11.361 & $12-07-88$ & $<1.0$ & $<.010$ & $<.010$ & .30 & 4.30 & 5.4 & 3.3 \\
\hline 15. 375 & $11-20-86$ & 2.0 & .018 & -- & -- & 3.30 & 3.2 & 2.2 \\
\hline $15-1048$ & $08-15-90$ & 2.2 & $<.010$ & $<.010$ & $<.20$ & .400 & 1.3 & .41 \\
\hline $15-1065$ & $07-17-90$ & 2.1 & .020 & $<.010$ & .50 & 4.70 & 4.6 & 3.8 \\
\hline 29- 88 & $07-12-90$ & 1.9 & $<.010$ & $<.010$ & .60 & 3.00 & 2.7 & 2.5 \\
\hline 29. 428 & $07-12-90$ & 2.9 & .030 & $<.010$ & .50 & 1.30 & 3.7 & .99 \\
\hline 29- 488 & $07-13-90$ & 1.5 & .020 & $<.010$ & $<.20$ & $<.100$ & .24 & .24 \\
\hline 29- 586 & $07-11-90$ & 1.4 & $<.010$ & $<.010$ & .40 & 1.30 & 1.1 & 1.2 \\
\hline 29- 735 & $07-11-90$ & $<1.0$ & .020 & $<.010$ & $<.20$ & .400 & .53 & .55 \\
\hline
\end{tabular}


Table 4. Physical properties of, concentrations of trace elements in, and lead isotope ratios in water samples from selected public supply wells in the Kirkwood-Cohansey aquifer system, New Jersey, 1993

$\left[{ }^{\circ} \mathrm{C}\right.$, degrees Celsius; $\mu \mathrm{S} / \mathrm{cm}$, microsiemens per centimeter at $25^{\circ} \mathrm{C}$; NTU, national turbidity units; mg/L, milligrams per liter; $\mu \mathrm{g} / \mathrm{L}$, microgram per liter; <, less than; --, data not available]

\begin{tabular}{|c|c|c|c|c|c|c|}
\hline $\begin{array}{c}\text { Well } \\
\text { number }\end{array}$ & Date & $\begin{array}{c}\text { Temperature, } \\
\text { water } \\
\left({ }^{\circ} \mathrm{C}\right)\end{array}$ & $\begin{array}{c}\text { Turbidity } \\
\text { (NTU) }\end{array}$ & $\begin{array}{c}\text { Specific } \\
\text { conductance } \\
(\mu \mathrm{S} / \mathrm{cm})\end{array}$ & $\begin{array}{c}\text { Oxygen, } \\
\text { dissolved } \\
(\mathrm{mg} / \mathrm{L})\end{array}$ & $\begin{array}{c}\text { pH, } \\
\text { water, } \\
\text { field } \\
\text { (standard } \\
\text { units) }\end{array}$ \\
\hline $01-230$ & $09-17-93$ & 15 & 20.0 & 45 & 4.9 & 5.1 \\
\hline $07-490$ & $09-08-93$ & 14 & .30 & 91 & 5.0 & 4.2 \\
\hline 07- 497 & $09-08-93$ & 13 & .60 & 54 & 5.4 & 5.2 \\
\hline $07-603$ & $09-10-93$ & 14 & .10 & 109 & 7.7 & 5.0 \\
\hline $07-69 I$ & $09-10-93$ & 13 & .30 & 78 & 3.4 & 5.3 \\
\hline $11-\quad 3$ & 09-29-93 & 14 & .20 & 118 & 11.2 & 4.6 \\
\hline $11-\quad 13$ & $09-28-93$ & 14 & .20 & 129 & 5.8 & 4.6 \\
\hline $11-\quad 20$ & $09-27-93$ & 15 & .20 & 90 & 5.6 & 4.7 \\
\hline 11- 254 & $09-24-93$ & 14 & 1.5 & 102 & 1.8 & 4.4 \\
\hline 11- 255 & $09-24-93$ & 14 & .20 & 74 & 4.1 & 4.5 \\
\hline II- 274 & $09-27-93$ & 14 & .20 & 126 & 7.1 & 4.7 \\
\hline $11-281$ & $09-28-93$ & 13 & .60 & 133 & 6.8 & 4.3 \\
\hline $11-361$ & $09-28-93$ & 14 & .20 & 122 & 5.3 & 4.7 \\
\hline 11- 712 & $09-15-93$ & 12.5 & .20 & 36 & 7.5 & 5.0 \\
\hline 15- 375 & $09-01-93$ & 13 & -. & 95 & 2.9 & 4.8 \\
\hline $15-1048$ & $09-01-93$ & 13 & -- & 60 & 6.6 & 5.0 \\
\hline $15-1065$ & $09-08-93$ & 13 & .20 & 103 & 8.0 & 4.5 \\
\hline $29-88$ & $09-07-93$ & 13 & .20 & 110 & 6.2 & 4.5 \\
\hline \multirow[t]{2}{*}{ 29- 428} & $09-09-93$ & 15 & 8.7 & 90 & 2.7 & 5.4 \\
\hline & $09-09-93$ & - & -- & -- & -- & -- \\
\hline 29- 488 & $09-03-93$ & 13 & .70 & 26 & .5 & 4.4 \\
\hline 29. 586 & $09-02-93$ & 14 & .10 & 76 & 5.8 & 4.7 \\
\hline 29- 735 & $09-02-93$ & 13 & .10 & 59 & 3.7 & -- \\
\hline
\end{tabular}


Table 4. Physical properties of, concentrations of trace elements in, and lead isotope ratios in water samples from selected public supply wells in the Kirkwood-Cohansey aquifer system, New Jersey, 1993--Continued

\begin{tabular}{|c|c|c|c|c|c|c|c|c|}
\hline $\begin{array}{c}\text { Well } \\
\text { number }\end{array}$ & Date & $\begin{array}{c}\text { Arsenic, } \\
\text { dissolved } \\
(\mu \mathrm{g} / \mathrm{L} \text { as As) }\end{array}$ & $\begin{array}{c}\text { Barium" } \\
\text { dissolved } \\
(\mu \mathrm{g} / \mathrm{L} \text { as Ba) }\end{array}$ & $\begin{array}{c}\text { Beryilium, } \\
\text { dissolved } \\
(\mu \mathrm{g} / \mathrm{L} \text { as Be) }\end{array}$ & $\begin{array}{c}\text { Cadmium', } \\
\text { dissolved } \\
(\mu \mathrm{g} / \mathrm{L} \text { as Cd })\end{array}$ & $\begin{array}{c}\text { Chromium', } \\
\text { dissolved } \\
(\mu \mathrm{g} / \mathrm{L} \text { as } \mathrm{Cr})\end{array}$ & $\begin{array}{c}\text { Cobalt, } \\
\text { dissolved } \\
(\mu \mathrm{g} / \mathrm{L} \text { as } \mathrm{Co})\end{array}$ & $\begin{array}{c}\text { Copper }^{1}, \\
\text { dissolved } \\
(\mu \mathrm{g} / \mathrm{L} \text { as } \mathrm{Cu})\end{array}$ \\
\hline $01-230$ & $09-17-93$ & $<1$ & 35 & $<1$ & $<1$ & $<1$ & 2 & 25 \\
\hline $07-490$ & $09-08-93$ & $<1$ & 59 & $<1$ & $<1$ & $<1$ & 1 & 8 \\
\hline 07. 497 & $09-08-93$ & $<1$ & $30(28.6)$ & $<1$ & $<1(.05)$ & $<1(0)$ & $<1$ & $3(2.1)$ \\
\hline $07-603$ & $09-10-93$ & $<1$ & $98(89.8)$ & $<1$ & $<1(.08)$ & $<1(0)$ & 2 & $11(11.2)$ \\
\hline $07-691$ & $09-10-93$ & $<1$ & $61(54.2)$ & $<1$ & $<1(.08)$ & $<1(0)$ & 1 & $10(11.7)$ \\
\hline $11-3$ & $09-29-93$ & $<1$ & 100 & $<1$ & $<1$ & $<1(0)$ & 2 & 12 \\
\hline $11-\quad 13$ & $09-28-93$ & $<1$ & $72(65.8)$ & $<1$ & $<1(.23)$ & $<1(0)$ & 3 & $12(11.4)$ \\
\hline $11-20$ & $09-27-93$ & $<1$ & $51(45.9)$ & $<1$ & $<1(.10)$ & $<1(0)$ & $<1$ & $18(19.7)$ \\
\hline $11-254$ & $09-24-93$ & $<1$ & $78(73.3)$ & $<1$ & $<1(.26)$ & $<1(0)$ & 8 & $29(33.0)$ \\
\hline $11-255$ & $09-24-93$ & $<1$ & 53 & $<1$ & $<1$ & $<1$ & $<1$ & 12 \\
\hline 11- 274 & $09-27-93$ & $<1$ & $180(149.8)$ & $<1$ & $<1(.14)$ & $<1(0)$ & 2 & $3(2.9)$ \\
\hline $11-281$ & $09-28-93$ & $<1$ & $91(80.9)$ & $<1$ & $<1(.19)$ & $<1(0)$ & 1 & $16(17.1)$ \\
\hline $11-361$ & $09-28-93$ & $<1$ & 53 & $<1$ & $<1$ & $<1$ & 2 & 2 \\
\hline $11-712$ & $09-15-93$ & $<1$ & 22 & $<1$ & $<1$ & $<$ I & $<1$ & 16 \\
\hline 15- 375 & $09-01-93$ & $<1$ & 69 & $<1$ & $<1$ & $<1$ & 3 & 3 \\
\hline $15-1048$ & $09-01-93$ & $<1$ & 28 & $<1$ & $<1$ & $<1$ & $<1$ & 20 \\
\hline $15-1065$ & $09-08-93$ & $<1$ & $140(127.3)$ & $<1$ & $<1(.07)$ & $<1(0)$ & 2 & $10(10.0)$ \\
\hline $29-\quad 88$ & $09-07-93$ & $<1$ & 53 & $<1$ & $<1$ & $<1$ & 4 & 17 \\
\hline \multirow[t]{2}{*}{$29-428$} & 09-09-93 & $<1$ & 22 & $<1$ & $<1$ & $<1$ & $<1$ & 14 \\
\hline & $09-09-93$ & $<1$ & 22 & $<1$ & $<1$ & $<1$ & $<1$ & 15 \\
\hline 29- 488 & $09-03-93$ & $<1$ & 20 & $<1$ & $<1$ & $<1$ & $<1$ & $<1$ \\
\hline 29- 586 & $09-02-93$ & $<1$ & $33(28.9)$ & $<1$ & $<1(.1)$ & $<1(0)$ & 1 & $29(30.4)$ \\
\hline 29. 735 & $09-02-93$ & $<1$ & 30 & $<1$ & $<1$ & $<1$ & 1 & 14 \\
\hline
\end{tabular}


Table 4. Physical properties of, concentrations of trace elements in, and lead isotope ratios in water samples from selected public supply wells in the Kirkwood-Cohansey aquifer system, New Jersey, 1993 --Continued

\begin{tabular}{|c|c|c|c|c|c|c|c|}
\hline $\begin{array}{c}\text { Well } \\
\text { number }\end{array}$ & Date & $\begin{array}{c}\text { Lead }^{1}, \\
\text { dissolved } \\
(\mu \mathrm{g} / \mathrm{L} \text { as } \mathrm{Pb})\end{array}$ & $\begin{array}{l}{ }^{206} \mathrm{~Pb} /{ }^{207} \mathrm{~Pb} \\
\text { Isotope ratio }\end{array}$ & $\begin{array}{c}\text { Manganese }{ }^{1}, \\
\text { dissolved } \\
(\mu \mathrm{g} / \mathrm{L} \text { as } \mathbf{M n})\end{array}$ & $\begin{array}{c}\text { Thalium, } \\
\text { dissolved } \\
(\mu \mathrm{g} / \mathrm{L} \text { as } \mathrm{Tl})\end{array}$ & $\begin{array}{c}\text { Molybdenum, } \\
\text { dissolved } \\
(\mu \mathrm{g} / \mathrm{L} \text { as Mo) }\end{array}$ & $\begin{array}{c}\text { Nickel }{ }^{1}, \\
\text { dissolved } \\
(\mu \mathrm{g} / \mathrm{L} \text { as Ni) }\end{array}$ \\
\hline $01-230$ & $09-17-93$ & 3 & -- & 21 & $<1$ & $<1$ & 2 \\
\hline $07-490$ & $09-08-93$ & 2 & -- & 25 & $<1$ & $<1$ & 1 \\
\hline 07- 497 & $09-08-93$ & $<1(.2)$ & $(1.23)$ & $16(15.7)$ & $<1$ & $<1$ & $<1(3.6)$ \\
\hline $07-603$ & $09-10-93$ & $<1(.3)$ & $(1.10)$ & $24(22.7)$ & $<1$ & $<1$ & $2(3.3)$ \\
\hline $07-691$ & $09-10-93$ & $<1(.5)$ & (1.12) & $82(79.3)$ & $<1$ & $<1$ & $3(5.6)$ \\
\hline $11-3$ & $09-29-93$ & 1 & -- & 16 & $<1$ & $<1$ & 3 \\
\hline $11-\quad 13$ & $09-28-93$ & $16(16.5)$ & (1.19) & $32(31.0)$ & $<1$ & $<1$ & $4(4.1)$ \\
\hline $11-20$ & $09-27-93$ & $6(6.1)$ & $(1.21)$ & $9(9.9)$ & $<1$ & $<1$ & $4(5.4)$ \\
\hline 11- 254 & $09-24-93$ & $11(12.0)$ & $(1.20)$ & $61(61.3)$ & $<1$ & $<1$ & $8(15.2)$ \\
\hline $11-255$ & $09-24-93$ & $<1$ & -- & 13 & $<1$ & $<1$ & 2 \\
\hline $11-274$ & $09-27-93$ & $1(.6)$ & $(1.24)$ & $25(24.3)$ & $<1$ & $<1$ & $3(3.9)$ \\
\hline $11-281$ & $09-28-93$ & $10(9.0)$ & $(1.27)$ & $17(17.1)$ & $<1$ & $<1$ & $2(2.3)$ \\
\hline $11-361$ & $09-28-93$ & $<1$ & -- & 17 & $<1$ & $<1$ & 3 \\
\hline $11-712$ & $09-15-93$ & 1 & -- & 4 & $<1$ & $<1$ & 1 \\
\hline 15- 375 & 09-01-93 & 5 & -- & 20 & $<1$ & $<1$ & 4 \\
\hline $15-1048$ & $09-01-93$ & 1 & -- & 8 & $<1$ & $<1$ & $<1$ \\
\hline 15- 1065 & 09-08-93 & $3(2.8)$ & $(1.18)$ & $35(32.8)$ & $<1$ & $<1$ & $2(2.3)$ \\
\hline $29-88$ & $09-07-93$ & 6 & -- & 27 & $<1$ & $<1$ & 3 \\
\hline \multirow[t]{2}{*}{ 29- 428} & 09-09-93 & $<1$ & -- & 36 & $<1$ & $<1$ & $<1$ \\
\hline & & $<1$ & -- & 36 & $<1$ & $<1$ & 1 \\
\hline 29- 488 & $09-03-93$ & $<1$ & -- & 6 & $<1$ & $<1$ & $<1$ \\
\hline 29- 586 & $09-02-93$ & $2(2.2)$ & $(1.20)$ & $17(16.4)$ & $<1$ & $<1$ & $2(3.5)$ \\
\hline 29. 735 & $09-02-93$ & 12 & .. & 11 & $<1$ & $<1$ & 2 \\
\hline
\end{tabular}


Table 4. Physical properties of, concentrations of trace elements in, and lead isotope ratios in water samples from selected public supply wells in the Kirkwood-Cohansey aquifer system, New Jersey, 1993 -Continued

\begin{tabular}{|c|c|c|c|c|c|c|c|c|}
\hline $\begin{array}{c}\text { Well } \\
\text { number }\end{array}$ & Date & $\begin{array}{c}\text { Silver, } \\
\text { dissolved } \\
(\mu \mathrm{g} / \mathrm{L} \text { as } \mathbf{A g})\end{array}$ & $\begin{array}{c}\text { Zinc', } \\
\text { dissolved } \\
(\mu \mathbf{g} / \mathbf{L} \\
\text { as } \mathbf{Z n})\end{array}$ & $\begin{array}{c}\text { Antimony, } \\
\text { dissolved } \\
(\mu \mathrm{g} / \mathrm{L} \\
\text { as } \mathrm{Sb})\end{array}$ & $\begin{array}{c}\text { Aluminum', } \\
\text { dissolved } \\
(\mu \mathrm{g} / \mathrm{L} \\
\text { as Al) }\end{array}$ & $\begin{array}{c}\text { Mercury, } \\
\text { dissolved } \\
(\mu \mathrm{g} / \mathrm{L} \\
\text { as } \mathrm{Hg})\end{array}$ & $\begin{array}{c}\text { Cranjum, } \\
\text { natural, } \\
\text { dissolved } \\
\text { ( } \mu \mathrm{g} / \mathrm{L} \\
\text { as } \mathrm{L})\end{array}$ & $\begin{array}{c}\text { Alkalinity. } \\
\text { lab } \\
(\mathrm{mg} / \mathrm{L} \text { as } \\
\left.\mathrm{CaCO}_{3}\right)\end{array}$ \\
\hline $01-230$ & $09-17-93$ & $<1.0$ & 47 & $<1$ & 40 & $<0.1$ & $<1$ & 5.4 \\
\hline 07- 490 & $09-08-93$ & $<1.0$ & 12 & $<1$ & 80 & $<.1$ & $<1$ & 3.0 \\
\hline 07- 497 & $09-08-93$ & $<1.0$ & $8(6.4)$ & $<1$ & $60(60.9)$ & $<.1$ & $<1$ & 4.0 \\
\hline $07-603$ & $09-10-93$ & $<1.0$ & $10(9.9)$ & $<1$ & $80(75.5)$ & .1 & $<1$ & 3.0 \\
\hline 07- 691 & $09-10-93$ & $<1.0$ & $110(99.6)$ & $<1$ & $30(29.2)$ & $<.1$ & $<1$ & 7.5 \\
\hline $11-3$ & $09-29-93$ & $<1.0$ & 64 & $<1$ & 200 & $<.1$ & $<1$ & $<1.0$ \\
\hline $11-13$ & $09-28-93$ & $<1.0$ & $7(7.9)$ & $<1$ & $330(325.8)$ & $<.1$ & $<1$ & 1.1 \\
\hline $11-20$ & $09-27-93$ & $<1.0$ & $22(21.2)$ & $<1$ & $260(256.2)$ & $<.1$ & $<1$ & $<1.0$ \\
\hline $11-254$ & $09-24-93$ & $<1.0$ & $89(87.9)$ & $<1$ & $580(589.7)$ & .1 & $<1$ & $<1.0$ \\
\hline $11-255$ & $09-24-93$ & $<1.0$ & 17 & $<1$ & 360 & $<.1$ & $<1$ & $<1.0$ \\
\hline $11-274$ & $09-27-93$ & $<1.0$ & $24(25.1)$ & $<1$ & $110(118.3)$ & $<.1$ & $<1$ & $<1.0$ \\
\hline 11- 281 & $09-28-93$ & $<1.0$ & $38(34.2)$ & $<1$ & $60(53.1)$ & $<.1$ & $<1$ & $<1.0$ \\
\hline $11-361$ & $09-28-93$ & $<1.0$ & 5 & $<1$ & 710 & $<.1$ & $<1$ & $<1.0$ \\
\hline 11- 712 & $09-15-93$ & $<1.0$ & 10 & $<1$ & 50 & $<.1$ & $<1$ & 1.8 \\
\hline 15- 375 & $09-01-93$ & $<1.0$ & 7 & $<1$ & 230 & $<.1$ & $<1$ & -. \\
\hline 15- 1048 & $09-01-93$ & $<1.0$ & 30 & $<1$ & 210 & $<.1$ & $<1$ & $-\cdot$ \\
\hline $15-1065$ & $09-08-93$ & $<1.0$ & $15(10.8)$ & $<1$ & $90(89.5)$ & .2 & $<1$ & 4.5 \\
\hline $29-88$ & $09-07-93$ & $<1.0$ & 130 & $<1$ & 150 & .2 & $<1$ & 1.6 \\
\hline \multirow[t]{2}{*}{ 29- 428} & $09-09-93$ & $<1.0$ & 26 & $<1$ & 90 & 1.1 & $<1$ & 1.5 \\
\hline & & $<1.0$ & 27 & $<1$ & 100 & 1.0 & $<1$ & -. \\
\hline 29- 488 & 09-03-93 & $<1.0$ & 8 & $<1$ & 90 & $<.1$ & $<1$ & $<1.0$ \\
\hline 29- 586 & 09-02-93 & $<1.0$ & $28(24.5)$ & $<1$ & $90(89.8)$ & .2 & $<1$ & -. \\
\hline 29- 735 & (09-02-93 & $<1.0$ & 7 & $<1$ & 380 & $<.1$ & $<1$ & -. \\
\hline
\end{tabular}

1 Concentration in parentheses and lead isotope ratios are those measured in split water samples analyzed by ICP-MS at the Rutgers University Chemistry Department laboratory 